\title{
Offshoring and Skill-upgrading in French Manufacturing: A Heckscher-Ohlin-Melitz View*
}

\author{
Juan Carluccio ${ }^{\dagger} \quad$ Alejandro Cuñat ${ }^{\ddagger}$ Harald Fadinger ${ }^{\S} \quad$ Christian Fons-Rosen $₫$
}

September 2015

\begin{abstract}
We present a factor-proportions trade model in which heterogeneous firms can offshore intermediate inputs subject to fixed offshoring costs. In the skill-abundant country, highproductivity firms offshore a larger range of labor-intensive inputs to the labor-abundant countries than low-productivity firms. Differently from the traditional versions of factorproportions trade theory, Heckscher-Ohlin forces operate at the within-industry level, leading to endogenous variation in skill intensity across firms that is positively correlated with firm productivity. Using French firm-level data for the years 1996 to 2007, we provide empirical support for the factor proportions channel through which offshoring to labor-abundant countries affects the firm-level skill intensities of French manufacturers.
\end{abstract}

KEY WORDS: offshoring, heterogeneous firms, firm-level factor intensities, HeckscherOhlin.

JEL CLASSIFICATION: F11, F12, F14

\footnotetext{
${ }^{*}$ We are grateful to numerous seminar participants at Banque de France, Bayreuth, Bergen, Copenhagen Business School, Central European University, CREI, ECARES, Essex, LSE, IIES, Humboldt, Innsbruck, Mannheim, Passau, Southampton, Surrey, Vienna, the CES-ifo Delphi Conference, the Barcelona GSE Summer Institute, the IVIE Workshop on Trade and Growth and the CES-ifo Venice Summer Institute for helpful comments. Cuñat gratefully acknowledges financial support by the Austrian Science Fund (FWF \#AP23424-G11) and the hospitality of CREI while revising this paper. Fons-Rosen gratefully acknowledges financial support by the Spanish Ministry of Economy and Competitiveness (ECO2014-55555-P).

${ }^{\dagger}$ Banque de France and University of Surrey. Email: juan.carluccio@gmail.com.

${ }^{\ddagger}$ University of Vienna and CES-ifo. Email: alejandro.cunat@univie.ac.at.

${ }^{\S}$ University of Mannheim. Corresponding author. Adress: Department of Economics, University of Mannheim, L7 3-5, D-68163 Mannheim, Germany. Email: harald.fadinger@uni-mannheim.de.

"Universitat Pompeu Fabra, Barcelona GSE, and CEPR. Email: christian.fons-rosen@upf.edu.
} 


\section{Introduction}

The heterogeneous-firm literature of the last 15 years has not only uncovered important withinindustry differences in productivity and export performance, but more recently also a substantial within-industry variation of skill intensities between firms, with skill intensities correlating positively with productivity. Although this within-sector variation is larger than differences in skill intensities between narrowly defined industries (e.g., Corcos et al., 2013), most of trade theory ignores it (e.g., the Heckscher-Ohlin model). The few studies that allow for within-sector heterogeneity in factor intensities simply take it as given (e.g., Crozet and Trionfetti, 2013). Similarly, some recent contributions just posit a positive correlation between productivity and factor intensities (e.g., Harrigan and Reshef, forthcoming).

In this paper, we present a factor-proportions model with heterogeneous firms and costly offshoring that endogenously generates within-industry dispersion in skill intensity, which correlates positively with firm productivity. Our study sheds light on the specific microeconomic channels that lead firms to self-select into offshoring and determine the type of goods they offshore, as well as the country characteristics of their offshoring destinations. We also show how changes in offshoring costs affect the relative demand for skills at the firm and the industry level. Moreover, we provide empirical evidence for the factor proportions mechanism of offshoring using a quasi-exhaustive panel dataset of French manufacturing firms for the period 1996-2007.

In the model, intermediate inputs differ in their relative factor intensities and countries have different relative factor endowments, as in the traditional Heckscher-Ohlin theory. Firms are heterogeneous in terms of productivity, and offshoring of intermediates requires the payment of per-input fixed offshoring costs. Firms must therefore weigh the lower marginal cost resulting from offshoring, say a labor-intensive input to a labor-abundant country, against the fixed costs implied by such a decision.

From the perspective of a skill-abundant country, in equilibrium, the low-productivity firms produce all inputs domestically. Sufficiently productive firms offshore the most labor-intensive inputs to very labor-abundant countries. Firms with even higher productivity levels find it profitable to also import relatively more skill-intensive inputs from not-so-labor-abundant countries. Such imports substitute for domestic unskilled employment, making domestic production more skill intensive. Thus, at the firm level, productivity and skill intensity of domestic production are positively correlated, generating endogenous within-industry variation in skill intensities. Reductions in offshoring costs lead to a boost in imports from labor-abundant countries and, 
simultaneously, to an increase in the skill bias of domestic production.

Our model is able to explain a set of stylized facts for the manufacturing industry in France (a skill-abundant country) linking firm productivity, import behavior, and the skill intensity of domestic employment, that we present in the empirical part of the paper. A first look at the data shows that the within-industry dispersion in skill intensities is much larger for importers from labor-abundant countries than for non-importers. Moreover, importers from labor-abundant countries are more skill intensive in their domestic production than non-importers, and the positive trend in offshoring to these countries since the mid-nineties runs parallel to the surge in the skill intensities of those importers. Our econometric analysis reveals an additional set of facts that square with our model's predictions: (i) the firm-level average skill intensity of imports from labor-abundant countries is positively correlated with firm productivity; (ii) for a given labor-abundant country of origin, more productive firms import more skill-intensive products on average; (iii) out of the set of labor-abundant countries, less productive firms import only from the most labor-abundant countries, while more productive firms import also from the relatively more skill-abundant ones; (iv) firms that increase imports from labor-abundant countries experience a substantial increase in their domestic skill intensities; (v) firms that raise the skill intensity of imports from labor-abundant countries increase the skill intensity of their domestic employment; (vi) our instrumental-variables estimates, which exploit supply shocks in France's trading partners and reductions in EU external tariffs, provide causal evidence that the increase in imports from labor-abundant countries (induced by foreign supply shocks and tariff reductions) has led to a substantial increase in the French manufacturing industry's skill intensity over the sample period. We find that all of the observed within-firm changes in skill intensity can be explained by increased offshoring to labor-abundant countries.

The insights of our work complement our understanding of a number of issues that have received much attention in the international trade literature. In particular, we highlight that an essential channel of factor proportions trade operates within industries and even within firms rather than between industries, which has been the focus of traditional Heckscher-Ohlin theory. This is important in order to understand the impact of international trade on factor prices and the factor content of trade. Whereas the between-industry variation in factor intensities is a necessary assumption in the standard Heckscher-Ohlin model, the within-industry variation arising here is a subtle manifestation of Heckscher-Ohlin forces at work in combination with firm-heterogeneity in size or productivity. Second, we provide microeconometric evidence on the relationship between offshoring and firm-level skill intensity that operates via the factor proportions channel. 
We contribute to different strands of the literature. Our modeling approach is inspired by Helpman (1984), who provides a Heckscher-Ohlin model of multinationals in which production is vertically disintegrated according to comparative advantage. Also closely related is Feenstra and Hanson (1997), where firms offshore some of their labor-intensive activities in response to liberalization of capital markets, thereby reducing the demand for skilled labor in the U.S. We extend their work by introducing firm heterogeneity into the theoretical framework, and by deriving and testing implications at the firm level. A quite different view of the effect of offshoring on factor demand and wages has been put forward by Grossman and Rossi-Hansberg (2008). In their model there exist complementarities between domestically performed and offshored tasks. As a consequence, offshoring of unskilled tasks may benefit both unskilled and skilled workers. In contrast, in our model offshoring and domestic production are perfect substitutes, thus offshoring reduces demand for the offshored factor and its price.

Our theoretical model fits in the literature of Heckscher-Ohlin trade with heterogeneous firms. Bernard, Redding and Schott (2007) build a two-country, two-sector, two-factor Melitz (2003) model, where sectors differ in their factor intensities, firms are homogeneous in terms of factor intensities within a given sector and all factor-proportions trade is in final goods between sectors. Recently, Crozet and Trionfetti (2013) have extended their model to allow for exogenous within-industry differences in factor intensities. In contrast, our model endogenously generates differences in factor intensities within sectors due to factor proportions trade in inputs. Ma et al. (2014) develop a multi-product version of Bernard et al. (2007) and show that Chinese firms that start exporting focus on their core competencies and expand the production of relatively labor-intensive products.

In a model with heterogeneous firms but with no factor proportions trade, Antràs et al. (2014) characterize offshoring patterns for U.S. firms and estimate them structurally using a quantitative multi-country, many-good model à la Eaton and Kortum (2002) that features complementarities between sourcing locations. Similarly to Antràs et al. (2014), our model delivers a natural pecking order of offshoring destinations, which, however, is determined by the forces of factorproportions-driven comparative advantage. In particular, firms from a skill-abundant country would first import the most labor-intensive inputs from the most labor-abundant countries, as these provide the largest cost reductions.

Our theory also delivers complementarities across offshoring destinations, though generated by a different mechanism than in Antràs et al. (2014). In particular, our model predicts that the impact of importing an additional country-product combination on a firm's global offshoring 
strategy depends on the country's factor abundance and the input's factor intensity: in the case of a firm located in a skill-abundant country, having lower offshoring costs to other countries or for other inputs leads firms to import more from a given location. In addition, this effect is stronger if the other sourcing countries are more labor abundant or when the other imported inputs are more labor intensive. We show that this prediction is borne by the data: for French firms importing from the set of labor-abundant countries, holding constant firm-level productivity, firms importing more labor-intensive products from other origin countries import a larger value from a given location; moreover, firms sourcing from relatively more labor-abundant countries import a larger value from any given country.

Finally, we also contribute to the empirical literature on offshoring and domestic skill demand using firm-level data. Kramarz and Biscourp (2007) study the effect of imports on employment growth and skill upgrading for a sample of French firms during 1986-1992. They find that imports of finished goods from low-wage countries are associated with lower employment growth, with the effects present only in the case of large firms. Mion and Zhu (2013), using data on Belgian firms, find that import competition from China induces skill upgrading of the domestic workforce. Hummels et al. (2014) employ data on Danish importers to provide evidence that employment and wages of high-skilled workers are positively affected by offshoring. ${ }^{1}$ In contrast to these papers, which are purely empirical, we investigate the specific theoretical mechanisms through which skill demand at the firm level is affected by offshoring to labor-abundant countries. In particular, we carefully measure the factor-proportions channel of importing and show that it matters for determining the skill intensity of domestic production.

\section{A Preliminary Look at the Data}

In this section, we describe some of the salient features of the French manufacturing employment and import data, which provide the motivation for our theoretical model. We use the administrative firm-level data that we describe in detail in Section 4.

We begin by analyzing the extent of intra-industry heterogeneity in firm-level skill intensities in French manufacturing. Figure 2 illustrates the amount of intra-industry heterogeneity in firm-level skill intensities by plotting the kernel density of the firm-level (log) skill ratio, defined as the proportion of non-blue-collar employment relative to blue-collar employment. Here, the

\footnotetext{
${ }^{1}$ Using French data, Carluccio et al. (2015) find that offshoring of finished goods increases the wages of managers but has no effect on the wages of blue-collar workers.
} 
variable of interest has been demeaned at the 4-digit sector level, so that the density can be interpreted as pure within-industry heterogeneity in firm-level (log) skill ratios. The distribution is approximately normal, with a standard deviation of 1.628. Thus, there is evidence for pervasive intra-industry heterogeneity in skill ratios.

Table 1 presents complementary evidence: for each year from 1996 to 2007 we report the mean, the standard deviation and the coefficient of variation (standard deviation/abs(mean)) of $(\log )$ skill ratios, as well as a within/between sector variance decomposition. The disaggregation of the manufacturing industries is again at the 4-digit level. The coefficient of variation is large (around 2.1) and 80 percent of the variance of skill intensity is explained by within-sector variation between firms, while only 20 percent of the variation is between sectors. These patterns are remarkably stable over time.

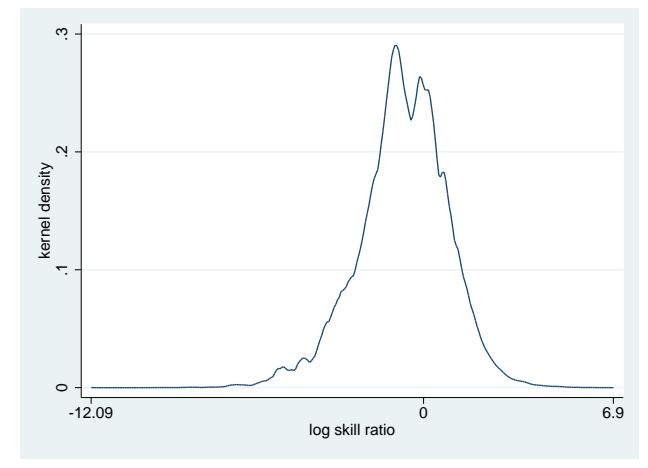

Figure 1: Distribution of log skill ratio.

The figure plots the distribution of the firm-level log skill ratio, defined as the ratio of employment of non-blue collar workers to blue-collar production workers per firm. Observations are deviations from the industry means. Thus, the distribution shows the within-sector dispersion in firm-level log skill ratios.

During the same sample period, offshoring to labor-abundant countries has gained much relevance in French manufacturing. Here, we define labor-abundant countries as those with less than 95 percent of the French level of secondary schooling in the population. ${ }^{2}$ The left panel of Figure 2 presents the aggregate trend in offshoring to labor-abundant countries measured as the fraction of imports of French manufacturing firms originating in labor-abundant countries: from 1996 to 2007 there has been a large increase in imports from these countries, from less than 16 to more than 20 percent of total French manufacturing imports.

The right panel of Figure 2 provides some preliminary evidence that the trends in skill intensities and offshoring patterns might be related. It shows that, at the same time, firms offshoring to

\footnotetext{
${ }^{2}$ In the robustness checks in the Online Appendix, we consider an 80-percent threshold and show that our results are not sensitive to the choice of the threshold.
} 


\begin{tabular}{ccccccc}
\hline \hline Year & Obs. & Mean & Std. Dev. & $\begin{array}{c}\text { Coeff. } \\
\text { Variation }\end{array}$ & $\begin{array}{c}\text { Frac. Variance } \\
\text { between sectors }\end{array}$ & $\begin{array}{c}\text { Frac. Variance } \\
\text { within sectors }\end{array}$ \\
\hline 1996 & 55,806 & -0.500 & 0.968 & 1.935 & 0.205 & 0.795 \\
1997 & 57,452 & -0.496 & 0.970 & 1.953 & 0.209 & 0.790 \\
1998 & 56,022 & -0.490 & 0.978 & 1.996 & 0.204 & 0.796 \\
1999 & 56,494 & -0.484 & 0.978 & 2.018 & 0.213 & 0.787 \\
2000 & 54,425 & -0.490 & 0.985 & 2.008 & 0.206 & 0.793 \\
2001 & 53,778 & -0.476 & 0.985 & 2.066 & 0.210 & 0.790 \\
2002 & 55,911 & -0.462 & 0.984 & 2.128 & 0.196 & 0.804 \\
2003 & 54,428 & -0.447 & 0.984 & 2.199 & 0.204 & 0.796 \\
2004 & 53,097 & -0.412 & 0.996 & 2.421 & 0.195 & 0.805 \\
2005 & 52,085 & -0.432 & 0.985 & 2.281 & 0.205 & 0.795 \\
2006 & 51,670 & -0.444 & 0.989 & 2.229 & 0.212 & 0.788 \\
2007 & 45,752 & -0.458 & 0.993 & 2.169 & 0.223 & 0.777 \\
\hline All & 646,920 & -0.467 & 0.983 & 2.105 & 0.200 & 0.800 \\
\hline \hline
\end{tabular}

Table 1: Firm-level skill ratio: dispersion and variance decomposition

The table shows means, standard deviations, and coefficients of variation (std./abs(mean)) of log firm-level skill intensity (defined as non-blue-collar employment/ employment of blue-collar production workers) for the sample of French manufacturing firms by year. It also presents the fraction of the total industry variance in skill intensity that is attributed to between-industry and within-industry variance.
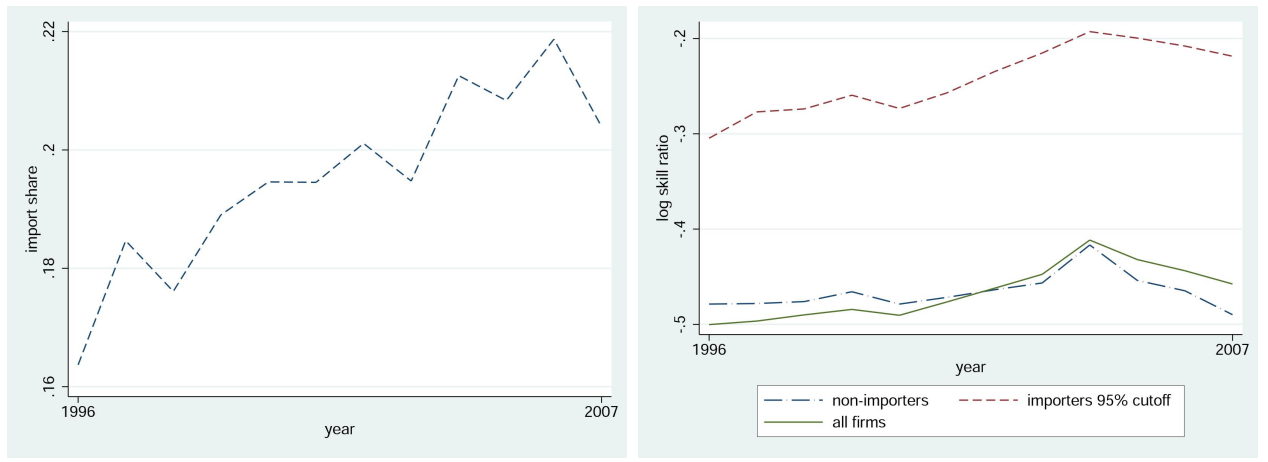

Figure 2: Trend in imports from labor-abundant countries and trends in log skill ratios.

The left panel plots the share of imports originating in labor-abundant countries (countries with less than 95 percent of the French level of secondary schooling) in total French manufacturing imports. The right panel plots the average firm-level log skill ratio, defined as the ratio of non-blue collar to blue-collar employment, separately for three categories of firms: importers from countries with less than 95 percent of the French level of secondary schooling; firms that never import; all manufacturing firms. 
labor-abundant countries have become substantially more skill-intensive (as far as their domestic labor force is concerned). It plots the mean (log) skill-ratio of French manufacturing firms, separately for all firms, importers from labor-abundant countries, and non-importers. Here importers are defined as firms that import in the current period from labor-abundant countries, while nonimporters are firms that never import during the sample period. It is apparent that, on average, French manufacturing firms have become more skill intensive during the sample period. Importantly, this increase is driven by importers from labor-abundant countries. By contrast, the skill-ratio of non-importers has hardly changed over the sample period.

Table 2 provides similar evidence. It shows the average skill intensity by year separately for non-importers and importers from labor-abundant countries. First, note that importers from labor-abundant countries are more skill-intensive than non-importers: the log skill ratio is -0.238 for importers from labor-abundant countries relative to -0.466 for non-importers. Moreover, the increase in skill intensity was also much larger for importers from labor-abundant countries (from -0.305 to -0.219) than for non-importers, for which it actually decreased during the sample period (from -0.479 to -0.490). Finally, Table 2 shows that importers from labor-abundant countries display a much larger dispersion in skill intensities than non-importers: the coefficient of variation is 4.538 for importers compared to 2.027 for non-importers. Moreover, such dispersion has increased relatively more for the group of importers than for the group of non-importers.

Finally, note that the firm-level (log) skill ratio is highly correlated with log (TFP): a simple regression reveals a highly significant slope coefficient of around 0.4. This relationship is robust to including sector- and year-fixed effects (regressions not reported). 


\begin{tabular}{|c|c|c|c|c|c|c|c|c|}
\hline & \multicolumn{4}{|c|}{ Non-Importers } & \multicolumn{4}{|c|}{ Importers (countries $\leq 95 \%$ French sec. school.) } \\
\hline Year & Obs. & Mean & Std. Dev. & $\begin{array}{c}\text { Coeff. } \\
\text { Variation }\end{array}$ & Obs. & Mean & Std. Dev. & $\begin{array}{c}\text { Coeff. } \\
\text { Variation }\end{array}$ \\
\hline 1996 & 30,386 & -0.479 & 0.932 & 1.947 & 6,007 & -0.305 & 1.056 & 3.469 \\
\hline 1997 & 30,815 & -0.478 & 0.933 & 1.951 & 6,455 & -0.277 & 1.083 & 3.908 \\
\hline 1998 & 29,296 & -0.476 & 0.939 & 1.972 & 6,851 & -0.274 & 1.092 & 3.984 \\
\hline 1999 & 29,670 & -0.466 & 0.940 & 2.018 & 7,210 & -0.259 & 1.082 & 4.171 \\
\hline 2000 & 28,298 & -0.479 & 0.946 & 1.977 & 7,599 & -0.274 & 1.084 & 3.965 \\
\hline 2001 & 27,810 & -0.472 & 0.944 & 2.002 & 7,831 & -0.257 & 1.105 & 4.299 \\
\hline 2002 & 29,110 & -0.464 & 0.941 & 2.030 & 8,325 & -0.235 & 1.010 & 4.686 \\
\hline 2003 & 28,040 & -0.456 & 0.943 & 2.067 & 8,453 & -0.215 & 1.093 & 5.081 \\
\hline 2004 & 27,328 & -0.418 & 0.965 & 2.316 & 8,749 & -0.193 & 1.078 & 5.597 \\
\hline 2005 & 26,866 & -0.454 & 0.949 & 2.090 & 9,139 & -0.199 & 1.075 & 5.387 \\
\hline 2006 & 26,971 & -0.465 & 0.955 & 2.054 & 9,494 & -0.208 & 1.065 & 5.123 \\
\hline 2007 & 23,658 & -0.490 & 0.957 & 1.954 & 9,075 & -0.219 & 1.064 & 4.868 \\
\hline All & 338,248 & -0.466 & 0.945 & 2.027 & 95,189 & -0.238 & 1.082 & 4.538 \\
\hline
\end{tabular}

Table 2: Firm-level skill ratio: importers from labor-abundant countries versus non-importers The table shows means, standard deviations, and coefficients of variation (std./abs(mean)) of log firm-level skill intensity (defined as non-blue-collar employment/ employment of blue-collar production workers) for the sample of French firms by year. It also presents the fraction of the total industry variance in log skill intensity that is attributed to between-industry and within-industry variance. "Non-importers" includes firms that never import during the sample period. "Importers (countries $\leq 95 \%$ French sec. school.)" includes firms that import from countries with years of secondary schooling in the population lower than $95 \%$ of that of France.

\section{The Model}

This section presents a stylized model of offshoring with heterogeneous firms in a Heckscher-Ohlin environment. For tractability purposes, we make a number of simplifying assumptions here, some of which are relaxed in the next section.

There are two countries, Home and Foreign (denoted by *), endowed with different amounts of skilled labor ("skills") $H$, and unskilled labor ("labor") $L$. We assume that Home is skill abundant, $H / L>H^{*} / L^{*}$. For simplicity, we assume a symmetric scenario, whereby $H=L^{*}>$ $L=H^{*}$. Other than this, the two countries are identical in their preferences, technologies, and parameter values.

There is one final-good industry, that we model roughly along the lines of Melitz (2003). Consumers derive utility from a Dixit-Stiglitz aggregate of final-good varieties:

$$
Q=\left[\int_{\omega \in \Omega} q(\omega)^{\frac{\sigma-1}{\sigma}} d \omega\right]^{\frac{\sigma}{\sigma-1}},
$$

where $\sigma>1$. $\Omega$ denotes the set of available varieties of the final good. Each firm produces a different variety of the final good, over which it has monopoly power. Varieties are produced with 
two intermediate inputs, $y_{1}$ and $y_{2}$. We assume the following production function for final goods:

$$
q(\gamma)=\gamma\left(\frac{y_{1}}{1 / 2}\right)^{1 / 2}\left(\frac{y_{2}}{1 / 2}\right)^{1 / 2}
$$

There is firm heterogeneity in the productivity $\gamma$ with which the two intermediates are transformed into output. We assume $\gamma$ is distributed Pareto with location parameter $k=1(\gamma \geq 1)$ and shape parameter $a>\sigma-1$, thus leading to the density $g(\gamma)=a \gamma^{-(a+1)}$. Intermediate inputs are produced with the "extreme" factor intensities specified in the following production functions: ${ }^{3}$

$$
\begin{aligned}
& y_{1}=h / \tau^{j}, \\
& y_{2}=l / \tau^{j},
\end{aligned}
$$

where $h$ is the skills input and $l$ is the labor input and $j=o, n$ denotes the decision of the firm whether to outsource $(o)$ or not $(n)$ the production of intermediate inputs. If the intermediate inputs are produced in-house by the final-good producers, then $\tau^{n}=1$. If produced out of the firm, then firms need to pay a variable iceberg outsourcing cost $\tau^{o} \in(1, H / L) .{ }^{4}$ This variable offshoring cost can be interpreted as a friction (e.g., a trade barrier) and as a cost or productivity disadvantage due to distance. Besides this variable iceberg cost, a fixed cost $f^{o}$ in terms of good $Q$ must be paid per type of intermediate input not produced in-house. International trade of final goods is subject to no variable transportation costs. Skills and labor are internationally immobile.

Factor and intermediate-input markets are perfectly competitive. Before entry, final-good producers must pay a fixed cost $f^{e}$ in terms of good $Q$ in order to pick a draw of $\gamma$. For simplicity, we assume no fixed cost must be paid in order to supply positive amounts of a variety to a particular market. Hence, all firms that incur the fixed cost $f^{e}$ operate in both the domestic and foreign markets regardless of their realization of $\gamma$.

We take the domestic return of skills as the numéraire: $w_{h}=1$ and denote the domestic unskilled labor wage rate with $w_{l}$. Given the model's symmetry, in equilibrium $M=M^{*}$, $E=E^{*}, P=P^{*}, w_{l}=w_{h}^{*}, w_{h}=w_{l}^{*}, \gamma_{o}=\gamma_{o}^{*}$, where $M$ is the mass of firms that incur fixed cost $f^{e}, P$ is the aggregate price index and $E \equiv w_{h} H+w_{l} L$ denotes expenditure. $\gamma_{o}$ is the threshold

\footnotetext{
${ }^{3}$ This assumption is harmless in terms of the intuitions discussed below, and simplifies the algebra notably.

${ }^{4}$ We avoid modeling any type of hold-up problem. See Antràs (2003) and Antràs and Helpman (2004).
} 
productivity level for offshoring, as explained below. ${ }^{5}$

\subsection{Offshoring Decision}

Notice that no firm finds it worth to outsource in the own country because of the outsourcing $\operatorname{costs}\left(f^{o}, \tau^{o}\right)$ and the lack of any cost advantage. Assuming $w_{l}=w_{h}^{*}>w_{h}=w_{l}^{*}=1$ (this will be proven below), it is not worth offshoring abroad the intermediate input intensive in the own country's abundant factor. ${ }^{6}$ Hence, the offshoring decision is reduced to a decision about whether or not to offshore abroad the intermediate input intensive in the own country's scarce factor. Since, in this respect, final-good producers will simply weigh the gain from a lower marginal cost against a fixed cost, we can model the offshoring decision as a threshold $\gamma_{o}$ : for $\gamma \geq \gamma_{o}$, the firm offshores the entire production of the intermediate input (intensive in the own country's scarce factor); for $\gamma<\gamma_{o}$, the firm produces the two intermediate inputs in-house.

This argument can be better understood by examining the profit function of Home's finalgood producers. They charge a markup $\sigma /(\sigma-1)$ over their marginal cost, and make profits (abstracting from the sunk cost $P f^{e}$ )

$$
\Pi^{j}(\gamma)=\left(\frac{\sigma}{\sigma-1}\right)^{1-\sigma} \frac{2 E}{\sigma P^{1-\sigma}}\left[M C^{j}(\gamma)\right]^{1-\sigma}-I(\gamma) P f^{o}
$$

where $j=o$ and $I(\gamma)=1$ for $\gamma \geq \gamma_{o}$ and $j=n$ and $I(\gamma)=0$ for $\gamma<\gamma_{o}$,

$$
\begin{aligned}
& M C^{o}(\gamma)=\gamma^{-1}\left(\tau^{o}\right)^{1 / 2} \\
& M C^{n}(\gamma)=\gamma^{-1} w_{l}^{1 / 2}
\end{aligned}
$$

The left panel of Figure 3 plots the profit function of equation (5) for $j=o, n$ against $\gamma^{\sigma-1}$. The function $\Pi^{o}\left(\gamma^{\sigma-1}\right)$ is steeper than $\Pi^{n}\left(\gamma^{\sigma-1}\right)$ because $M C^{o}(\gamma)<M C^{n}(\gamma){ }^{7}$

\subsection{Equilibrium}

The model's equilibrium conditions can be expressed as follows: ${ }^{8}$

\footnotetext{
${ }^{5}$ As we discussed, the model's symmetry implies that the labor-abundant country is a mirror image of the skill-abundant one. This would not be the case if, for example, the labor-abundant country had a comparative disadvantage in assembling the final goods. In this case, trade patterns would consist primarily of final goods being exported by the skill-abundant country in exchange for the labor-intensive intermediates.

${ }^{6}$ The assumption that $w_{h}<w_{l}$ is admittedly rather unrealistic. This is an artifact of symmetry. The key results of the model would not change if we allowed for productivity shifts for skilled workers. All that matters for our results is that the skill premium in the skill-abundant country is lower than in the labor-abundant country.

${ }^{7}$ Below we prove that $w_{l}>\tau^{o}$ in equilibrium.

${ }^{8}$ Given the model's symmetry, we need only need to consider the equilibrium conditions related to Home.
} 

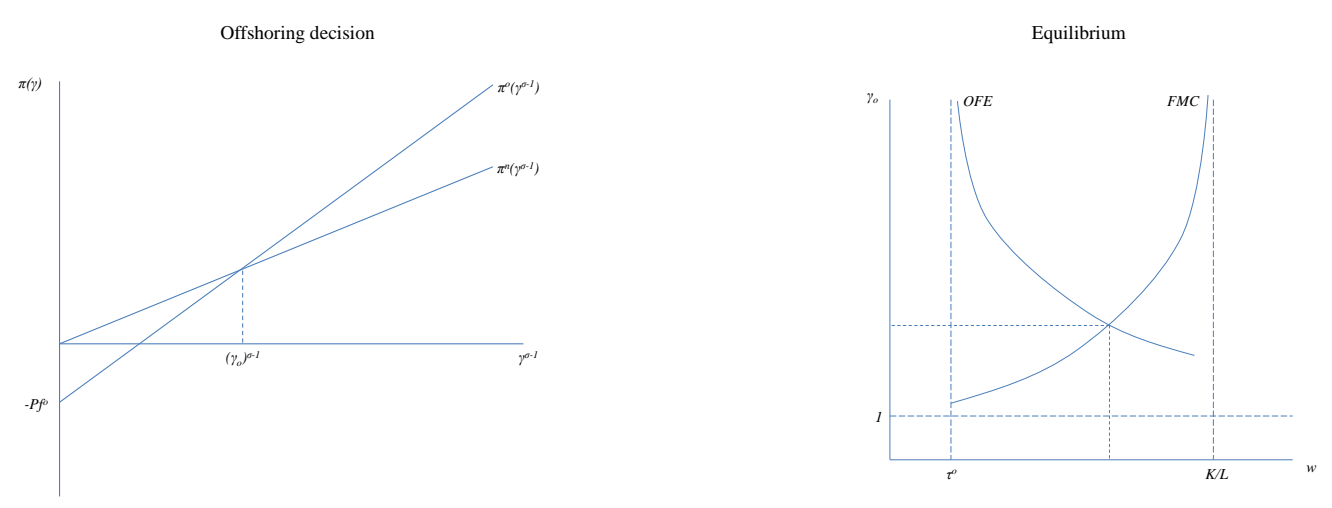

Figure 3: Offshoring decision (left panel), general equilibrium (right panel).

1. The final-good firm's indifference between offshoring or not $\left(\Pi^{o}\left(\gamma_{o}\right)=\Pi^{n}\left(\gamma_{o}\right)\right)$ pins down the threshold productivity level $\gamma_{o}$ :

$$
\left(\frac{\sigma}{\sigma-1}\right)^{1-\sigma} \frac{2 E}{\sigma P^{1-\sigma}}\left[M C^{o}\left(\gamma_{o}\right)^{1-\sigma}-M C^{n}\left(\gamma_{o}\right)^{1-\sigma}\right]-P f^{o}=0
$$

2. The price level $P$ is simply the CES ideal price index. Given the symmetry assumptions we impose, it simplifies to

$$
P^{1-\sigma}=2 M\left(\frac{\sigma}{\sigma-1}\right)^{1-\sigma}\left[\int_{1}^{\gamma_{o}}\left(\gamma^{-1} w_{l}^{1 / 2}\right)^{1-\sigma} d G(\gamma)+\left(\tau^{o}\right)^{\frac{1-\sigma}{2}} \int_{\gamma_{o}}^{\infty} \gamma^{\sigma-1} d G(\gamma)\right]
$$

3. Free entry leads to expected zero profits for the producers of final-good varieties. Notice that, in comparison with Melitz (2003), all firms paying fixed cost $f^{e}$ will produce positive amounts, as we assume away the presence of fixed associated to supplying individual markets. ${ }^{9}$

$$
\int_{1}^{\infty}\left[\left(\frac{\sigma}{\sigma-1}\right)^{1-\sigma} \frac{2 E}{\sigma P^{1-\sigma}}\left[M C^{j}(\gamma)\right]^{1-\sigma}-P I^{j}(\gamma) f^{o}\right] d G(\gamma)=P f^{e}
$$

4. Putting together the market clearing conditions for skills and labor,

$$
\frac{\frac{1}{2} \int_{1}^{\gamma_{o}}\left(\gamma^{-1} w_{l}^{1 / 2}\right)^{1-\sigma} d G(\gamma)+\left(\tau^{o}\right)^{\frac{1-\sigma}{2}} \int_{\gamma_{o}}^{\infty} \gamma^{\sigma-1} d G(\gamma)}{\frac{1}{2} w_{l}^{-1} \int_{1}^{\gamma_{o}}\left(\gamma^{-1} w_{l}^{1 / 2}\right)^{1-\sigma} d G(\gamma)}=\frac{H}{L} .
$$

\footnotetext{
${ }^{9}$ The assumption that fixed costs are in terms of $\operatorname{good} Q$ leads to a "tricky" issue. For $\sigma=2$ the price level $P$ cancels out from the free-entry condition: when $P$ changes, revenues and fixed costs move in lockstep, thus leaving profits unaffected. This leads to the indeterminacy of $M$. To avoid this problem, we impose the constraint $\sigma>2$. In this case, revenues rise faster than fixed costs with an increase in $P$.
} 
The first term in the numerator is associated to the demand for Home's skills by the Home firms that do not offshore. The second term in the numerator is associated to the demand for Home's skills by offshoring Home and Foreign firms. Finally, the term in the denominator is associated to the demand for Home's labor by the Home firms that do not offshore. Home's (and Foreign's) offshoring firms do not demand any Home labor.

Condition 4 can be rewritten as

$$
\Phi_{F M C}\left(\gamma_{o}, w_{l}, H / L, \tau^{o}\right)=\gamma_{o}^{a-\sigma+1} \frac{\frac{1}{2} w_{l}^{\frac{1-\sigma}{2}}\left(w^{-1} H / L-1\right)}{\frac{1}{2} w_{l}^{\frac{1-\sigma}{2}}\left(w_{l}^{-1} H / L-1\right)+\left(\tau^{o}\right)^{\frac{1-\sigma}{2}}}=1
$$

whereas conditions 1-3 yield

$$
\Phi_{O F E}\left(\gamma_{o}, w_{l}, H / L, \tau^{o}, f^{e} / f^{o}\right)=\frac{\frac{a-\sigma+1}{a} \gamma_{o}^{\sigma-1}\left[\left(\tau^{o}\right)^{\frac{1-\sigma}{2}}-w_{l}^{\frac{1-\sigma}{2}}\right]\left(\gamma_{o}^{-a}+f^{e} / f^{o}\right)}{w_{l}^{\frac{1-\sigma}{2}}\left(1-\gamma_{o}^{\sigma-a-1}\right)+\gamma_{o}^{\sigma-a-1}}=1 .
$$

Equations (12) and (13) constitute a system of two non-linear equations in $w_{l}$ and $\gamma_{o}$. Once we solve this system, we can find positive solutions for $M$ and $P$ from conditions 2 and 3 (see the Appendix).

We now characterize the schedules $\gamma_{o}\left(w_{l}\right)$ that result from equations (12) and (13), and discuss some comparative statics exercises. (See the right panel of Figure 3 for a graphical representation and the Appendix for details). Our arguments are based on the guess that the solution must entail $\tau^{o}<w_{l}<H / L$, which will be verified. This guess is obviously not random. First, it is easy to see that prohibitive costs of offshoring (e.g. $f^{o}=\infty, \tau^{o}=\infty$ ) lead to an equilibrium in which $w_{l}=H / L$. Since offshoring reduces the relative demand for each country's scarce factor, we should expect a lower $w_{l}$ when offshoring costs are not prohibitive. Second, notice from our discussion above on the offshoring decision that $\tau^{o}>w_{l}$ would imply no offshoring, ruling out the realization of gains from trade in the model. The factor-market clearing condition (12) yields a positive relationship between $\gamma_{o}$ and $w_{l}$ : the fewer firms offshore, the stronger the relative demand for labor at home, and therefore the higher the relative factor price $w_{l}$. For $w_{l}=1, \gamma_{o}>1 .{ }^{10}$ Since $\gamma_{o}^{F M C}\left(w_{l}\right)$ is continuous and positively sloped, for $w_{l}=\tau^{o}>1, \gamma_{o}>1$, too. Finally, $\gamma_{o} \rightarrow \infty$ is associated with $w_{l} \rightarrow H / L$ : if no firm offshores, then the relative wage matches its counterpart for the case with prohibitive offshoring costs.

\footnotetext{
${ }^{10} \gamma_{o}=1$ would violate labor-market equilibrium, as no firm would employ unskilled workers.
} 
Notice that equation (13) can only hold for $w_{l}>\tau^{o}$. Under the (sufficient) condition ${ }^{11}$

$$
\frac{a-\sigma+1}{\sigma-1} \frac{f^{o}}{f^{e}}<1
$$

equation (13) yields a negative relationship between $\gamma_{o}$ and $w_{l}$ : the higher the relative factor price $w_{l}$, the more home firms find it optimal to offshore. $w_{l} \rightarrow \tau^{o}$ is associated with $\gamma_{o} \rightarrow \infty$ : for a relative wage $w_{l}=\tau^{o}$, no firm finds it optimal to offshore for a positive $f^{o}$.

The characteristics of these two schedules guarantee the existence of a unique intersection in the sub-space $\left[w_{l} \times \gamma_{o} \mid w_{l} \in\left(\tau^{o}, H / L\right), \gamma_{o} \in(1, \infty)\right]$. In spite of the model's Heckscher-Ohlin "flavor", the equilibrium does not yield factor price equalization because of the offshoring frictions. ${ }^{12}$ We now derive a number of comparative-statics results.

\subsection{Comparative Statics}

The tractability of the model enables us to carry out a number of comparative statics exercises:

1. An increase in $f^{o}$ shifts the OFE-schedule upwards, thus leading to a higher $\gamma_{o}$ and a higher $w_{l}$. A higher $f^{o}$ makes offshoring non profitable for some firms; this raises the relative demand for labor, thus raising its relative price $w_{l}$.

2. An increase in $\tau^{o}$ shifts the OFE-schedule upwards (a higher $\tau^{o}$ reverses the profitability of offshoring for some firms) and the FMC-schedule downwards (for a given $\gamma_{o}^{*}=\gamma_{o}$, the relative demand for the abundant factor by the rest of the world decreases, as offshoring is now subject to a higher variable cost). Thus, an increase in $\tau^{o}$ raises $w_{l}$. The Appendix shows that the effect on $\gamma_{o}$ is also unambiguously positive, that is, the vertical upward shift of the OFE-schedule dominates the shift of the FMC-schedule in the opposite direction. In the empirical section below we will interpret changes in $\tau^{o}$ as variation in import tariffs or, alternatively, as foreign export supply shocks. Observe that a reduction in $\tau^{o}$ can also be interpreted as a positive aggregate productivity shock.

3. An increase in $f^{e}$ shifts the OFE-schedule downwards, thus leading to a lower $\gamma_{o}$ and a

\footnotetext{
${ }^{11}$ Recall that equation (13) is the result of combining equilibrium conditions 1-3. When differentiating (13) with respect to $\gamma_{o}$, we come across effects that operate in different directions in the numerator of equation (14): (i) The difference in variable profits under offshoring and non-offshoring of condition 1 depends positively on $\gamma_{o}$, since more productive firms experience a larger increase in profits from offshoring given their larger sales. (ii) The fixed costs that enter the free-entry condition 3 depend negatively on $\gamma_{o}$ as the probability of paying the fixed cost to offshore decreases with a higher offshoring threshold productivity level. Sufficient equation (14) assumes that the former effect is stronger than the latter. This enables us to sign the derivative of (13) with respect to $\gamma_{o}$ as positive, and subsequently the implicit derivative of $\gamma_{o}$ with respect to $w_{l}$ as negative. Notice that the sufficient condition holds for an $f^{o}$ sufficiently small relative to $f^{e}$.

${ }^{12}$ It is easy to show that as long as $f^{o}>0$ factor price equalization is not possible (even if $\left.\tau^{o}=1\right)$.
} 
lower $w_{l}$. The higher $f^{e}$, the less firms in the market; this raises the price level $P$, and makes firms larger (in terms of sales); therefore it pays off for more firms to offshore, thus leading to downward pressure on the relative factor price $w_{l}$.

4. An increase in $H / L$ shifts the FMC-schedule to the right, thus leading to a lower $\gamma_{o}$ and a higher $w_{l}$. A higher $H / L$ makes labor relatively more scarce; this raises the relative price of labor, and makes offshoring profitable for firms with lower productivity levels.

The two-sector model captures most of the stylized facts, which we have described in section 2: it generates within-sector heterogeneity in skill intensity; moreover, skill intensity correlates positively with productivity; finally, firms that offshore to labor-abundant countries are more skill-intensive in their domestic production than non-offshorers.

\subsection{A Many-country Model with a Continuum of Intermediate Inputs}

In this section we extend our framework in order to derive a number of additional empirical implications of our theory. We consider a world composed of three countries that differ in their relative factor prices, and assume that final-good firms in all countries produce their final varieties with a continuum of intermediate inputs, each produced with a different skill intensity. In this extended setup, firms face an offshoring decision which includes (i) whether to offshore or not, (ii) which range of inputs to offshore, and (iii) from which country of origin.

Here are the changes in the assumptions that we make:

1. There are three countries indexed with $j=1,2,3$.

2. Firms make final goods by assembling a continuum of intermediate inputs

$$
q(\gamma)=\gamma \exp \left[\int_{0}^{1} \ln x(z) d z\right]
$$

where $\gamma$ is firm-specific. $x(z)$ denotes the quantity of intermediate input $z$ used in the production of the final-good variety.

3. Intermediate inputs are produced with the following Cobb-Douglas technologies:

$$
y(z)=\frac{Z(z)}{\tau^{j}} h(z)^{z} l(z)^{1-z},
$$

where $y(z)$ denotes the quantity produced of intermediate input $z ; Z(z)=z^{-z}(1-z)^{z-1}$; and $h(z)$ and $l(z)$ denote, respectively, the skills and labor allocated to the production of intermediate input $z$. Notice that skill intensities are increasing in $z$. 

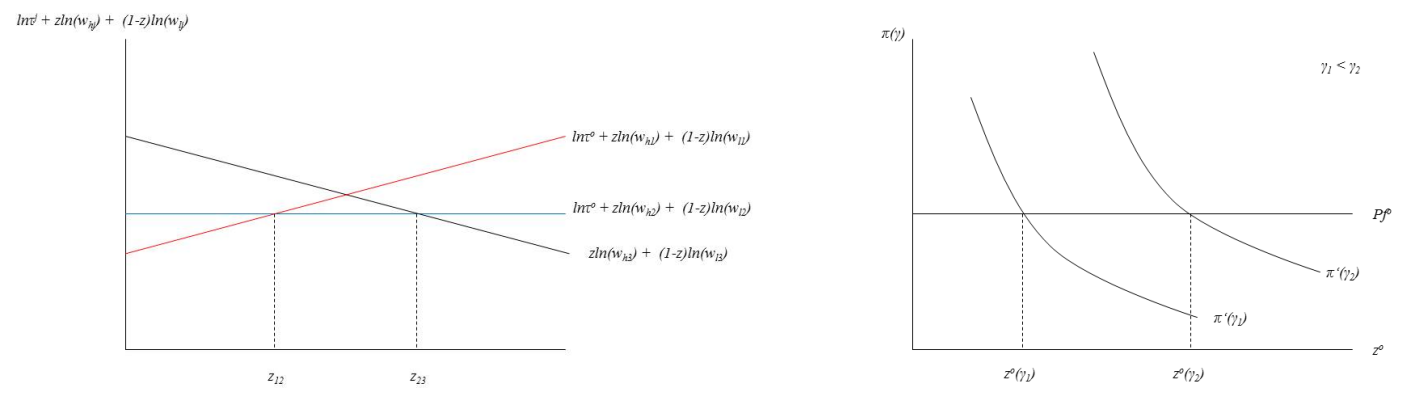

Figure 4: Cost function (left panel), offshoring decision (right panel)

4. Firms are now allowed to choose different ranges of offshored intermediates. They have to incur a fixed cost $f^{o}$ (in terms of the final good $Q$ ) per input offshored. Intermediate inputs are also subject to the variable offshoring $\operatorname{cost} \tau^{o}>1$. For simplicity, we assume for the moment that $\tau^{o}$ is equal across all country pairs.

We choose the wage of unskilled workers in country 2 as the numéraire: $w_{l 2}=1$. The complexity of the extended model prevents us from solving for the general equilibrium analytically. We assume $w_{h 1}=w_{l 3}>w_{l 2}=w_{h 2}=1>w_{l 1}=w_{h 3} \cdot{ }^{13}$ We focus on the offshoring decision of firms located in skill-abundant country 3 - in our empirical section, we will think of France as country 3. The left panel of Figure 4 plots the logarithm of the unit cost function of input $z$ if offshored to countries 1 or 2 (inclusive of the variable offshoring $\operatorname{cost} \tau^{o}$ ) and if produced in-house in country 3 . In labor-abundant country 1 unit costs of inputs rise with skill intensity, whereas in the skill-abundant country 3 unit costs of inputs decrease with skill intensity. The line is horizontal in the case of the intermediate country $2 .{ }^{14}$

Following standard Heckscher-Ohlin intuition, countries' comparative advantages depend on their relative endowments: labor-abundant country 1 has a comparative advantage in low- $z$ goods, skill-abundant country 3 has a comparative advantage in high- $z$ goods, and country 2 has a comparative advantage in the production of goods that are neither too labor-intensive nor too skill-intensive. By continuity, it is possible to derive cutoff points defining the range of inputs for

\footnotetext{
${ }^{13}$ This will be the case if we assume a symmetric world as far as factor endowments are concerned: $H_{1}=L_{3}<$ $H_{2}=L_{2}<H_{3}=L_{1}$. International differences in relative factor endowments must also be large enough in order for transport costs not to make trade in inputs prohibitive. In unreported numerical simulations we confirm this result in general equilibrium.

${ }^{14}$ These stark results are driven by the model's symmetry assumption. In a more general model, we would at least have the same patterns in relative terms.
} 
which each country has the lowest production costs (inclusive of the variable offshoring $\operatorname{cost} \tau^{o}$ from country 3$)$ : $\left[0, z_{12}\right]$ for country $1,\left(z_{12}, z_{23}\right)$ for country 2 , and $\left[z_{23}, 1\right]$ for country $3 .^{15}$

Following the intuition of the two-input model, offshoring decisions will vary by firm within each country. Given the structure of costs illustrated in the left panel of Figure 4, firms in country 3 will only find it profitable to offshore inputs that are on average more labor-intensive than those produced in-house, since offshoring inputs in the range $\left[0, z_{23}\right)$ reduces the marginal cost of country-3 producers of final-good varieties.

The profit function of a country-3 firm can be expressed as

$$
\Pi\left[\gamma, z_{3}^{o}(\gamma)\right]=\pi\left[\gamma, z_{3}^{o}(\gamma)\right]-z_{3}^{o}(\gamma) P f^{o}-P f^{e}
$$

with $\pi\left[\gamma, z_{3}^{o}(\gamma)\right]=p\left[\gamma, z_{3}^{o}(\gamma)\right] q\left[\gamma, z_{3}^{o}(\gamma)\right]-M C\left[\gamma, z_{3}^{o}(\gamma)\right] q\left[\gamma, z_{3}^{o}(\gamma)\right]$ denoting variable profits. The offshoring decision of an individual producer in country 3 can be represented by a cutoff input $z_{3}^{o}(\gamma) \leq z_{23}$ that denotes the most labor-intensive input produced in-house.

The firm-level offshoring patterns that can be derived from the maximization of profit function (17) constitute the main firm-level predictions of our theory, and share many of the intuitions we derived in the two-input model: country-3 firms will simply weigh the marginal increase in variable profits from offshoring a larger range of labor-intensive inputs to more labor-abundant countries against the marginal cost of doing so. The marginal increase in variable profits from offshoring decreases with the skill intensity of offshored inputs: the higher the skill intensity, the lower the difference in unit costs between country 1 and country 3, or between country 2 and country 3. The marginal cost of offshoring $P f^{o}$ is invariant to skill intensity. Thus, country-3 firms will always start by offshoring the most labor-intensive inputs to country 1 , and sufficiently productive firms might also source from country 2.

The right panel of Figure 4 plots the marginal increase in variable profits from offshoring additional inputs and the marginal cost of offshoring against $z$. The intersection of the two curves pins down the optimal cutoff $z_{3}^{o}(\gamma)$ that defines the range of offshored inputs. In the Appendix we show $\partial \pi\left(\gamma, z_{3}^{o}\right) / \partial z_{3}^{o}>0$ and $\partial^{2} \pi\left(\gamma, z_{3}^{o}\right) / \partial z_{3}^{o} \partial \gamma>0$. Variable profits $\pi\left(\gamma, z_{3}^{o}\right)$ increase with the cutoff $z_{3}^{o}$ because a larger $z_{3}^{o}$ implies lower marginal costs. A higher productivity $\gamma$ enhances this effect, as more productive firms have higher variable profits other things equal. Thus, more productive (larger) firms will find it optimal to offshore a larger range of intermediate inputs

\footnotetext{
${ }^{15}$ For example, input $z_{12}$ is equally expensive to offshore to countries 1 and 2 , whereas inputs $z<z_{12}$ are cheaper to offshore to more labor-abundant country 1 . Inputs $z \in\left(z_{12}, z_{23}\right)$ are cheaper to offshore to not-so-labor-abundant country 2 than to offshore to country 1 or to produce in-house in country 3 .
} 


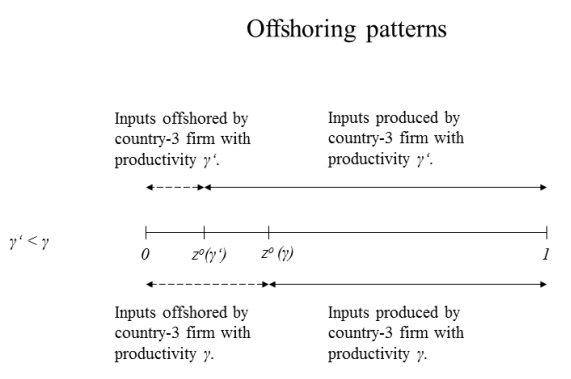

Three-country, many-good model

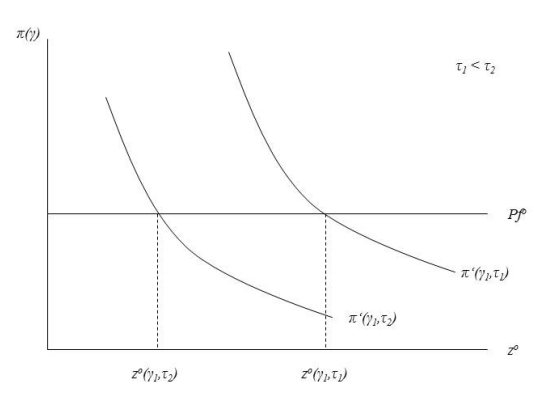

Figure 5: Offshoring range (left panel), change in offshoring cost (right panel)

(that is, they have a larger $z_{3}^{o}$ ), thereby keeping in-house production of the very skill-intensive inputs only.

Notice the resulting positive correlation between the skill intensity of offshored inputs and the skill intensity used in-house by the firm. The left panel of Figure 5 illustrates these patterns: a country-3 firm with a high productivity $\gamma$ offshores a wider range $\left[0, z_{3}^{o}(\gamma)\right]$ of intermediate inputs than a firm with lower productivity $\gamma^{\prime}<\gamma: z_{3}^{o}\left(\gamma^{\prime}\right)<z_{3}^{o}(\gamma)$. This makes the average skill intensity of the range increase in comparison with a low-productivity firm. At the same time, this implies that the firm produces a more skill-intensive input mix in-house $\left(z_{3}^{o}(\gamma), 1\right]$.

Moreover, note that more productive firms in country 3 will offshore a more skill-intensive mix of inputs by country. Besides, for a given source country, this input mix will also be more heterogeneous in terms of skill intensities for more productive firms, as their imports span a wider range of inputs. Notice also that according to the model the skill-abundant country's more productive firms offshore to a set of countries that is more heterogeneous in terms of skill abundance: highly productive country-3 firms will find it profitable to offshore not only to country 1 , but also to country 2 , whereas low-productivity firms may choose not to offshore at all, or offshore to labor-abundant country 1 only.

Regarding changes in offshoring costs, the Appendix shows that $\partial^{2} \pi\left(\gamma, z_{3}^{o}\right) / \partial z_{3}^{o} \partial \tau^{o}<0$ : as illustrated in the right panel of Figure 5, a decrease in the variable offshoring $\operatorname{cost} \tau^{o}$ makes it more profitable to offshore inputs, thus increasing the optimal range of offshored goods for country-3 firms. In addition, a decrease in $\tau^{o}$ will raise the share of imports in total sales as imported inputs substitute away in-house produced tasks both through the intensive margin (an 
increase in the volume imported of offshored inputs) and the extensive margin (an increase in the number of offshored inputs).

As mentioned in the introduction, our theory also has implications about complementarities across sourcing locations. The two examples that follow illustrate the kinds of arguments one can build upon our model in this respect. Consider two firms from country 3 with the same productivity $\gamma$. Assume that they face different variable offshoring costs, high or low, for different ranges of inputs: in particular, let us assume firm 1 has low offshoring costs for the most laborintensive decile of inputs whereas firm 2 has low offshoring costs for the second most laborintensive decile. Consider a situation in which $\gamma$ is large enough and both firms offshore these two ranges of inputs. The resulting decrease in marginal costs is larger for firm 1 than for firm 2. Firm 1's revenues will be higher, thus making it more likely that it offshores a larger volume of inputs and to more countries than firm 2, even if offshoring costs for these other countries or inputs are the same across the two firms.

Consider now a many- $(>3)$ country world in which the fixed offshoring costs firms face, high or low, vary by country. Let us assume firm 1 has low fixed offshoring costs vis-à-vis the most labor-abundant country. Firm 2, with identical productivity level, has a low fixed offshoring cost vis-à-vis some other country. Having a low offshoring cost vis-à-vis the most labor-abundant country will give firm 1 a larger cost reduction, thus enabling it to gain size in comparison with firm 2: firm 1 is therefore more likely to offshore a larger volume of inputs to any given country, even if offshoring costs for these other countries and inputs are the same across the two firms.

\subsection{Summary of Empirical Predictions}

A number of testable predictions arise from our theory, which we summarize below. From the perspective of France, which is a skill-abundant country:

1. There is significant variation in the skill intensity of production across French firms within a given sector; there is more variation in skill intensity across firms that import from laborabundant countries than across non-importing firms.

2. For French firms importing from labor-abundant countries, the skill intensity of imports is increasing in firm-level productivity.

3. Holding constant a given labor-abundant source country, more productive firms import more skill-intensive goods from that country compared to less productive ones; in addition, more productive firms have more variation in the skill intensity of their imports from a given labor- 
abundant country compared to less productive ones.

4. For French firms importing from the set of labor-abundant countries, less productive ones import only from the most labor-abundant countries, while more productive firms import also from relatively more skill-abundant countries; moreover, more productive firms have more variation in the skill abundance of countries from which they import compared to less productive ones.

5. For French firms importing from the set of labor-abundant countries, holding constant firmlevel productivity, firms importing more labor-intensive products from other import destinations import a larger volume from a given country of origin; moreover, firms sourcing from more laborabundant countries import a larger volume from any given country of origin.

6. French firms that import from the set of labor-abundant countries are more skill-intensive in their production in France than French non-importers and French firms that import from other countries.

7. For French firms importing from the set of labor-abundant countries, the skill intensity of their production in France is increasing in the skill intensity of their imports from those countries.

\section{Data}

\section{Firm-level Data}

Our empirical analysis is based on a detailed French firm-level dataset that we obtain by merging several administrative data sources using a common firm identifier.

Trade data: Firm-level trade data come from an exhaustive administrative file collected by the French Customs Office. The yearly value of imports (by country of origin and product) and exports (by country of destination and product) are reported for all firms over the period $1996-2007 .{ }^{16}$

Balance sheet data: The administrative BRN dataset ("Bénéfices Réels Normaux") is constructed from tax records and provides balance-sheet information by year. We use data on sales, employment, material usage, capital stock and main sector of activity at the 5-digit NAF Rev2 level. ${ }^{17}$ The dataset includes over $60 \%$ of French firms. We use the BRN data to estimate

\footnotetext{
${ }^{16}$ The data is virtually exhaustive. Flows with non-EU countries whose value is below 1,000 Euros are not in the dataset. In the case of EU countries, the threshold is larger, varying from 40,000 to 150,000 Euros depending on the year. These thresholds leave out a very small proportion of French trade flows.

${ }^{17} \mathrm{NAF}=$ French classification of economic activities, the first four digits of which are identical to the NACE Rev2 classification
} 
firm-level total factor productivity (TFP) as the residual of a Cobb-Douglas production function, separately for each 2-digit industry using data on 1,026,147 observations over the period 1994-2009. Our preferred measure uses the Levinsohn and Petrin (2003) method.

Employment by skill data: We obtain information on the occupational structure at the firm level using the DADS dataset ("Déclaration Annuelle de Données Sociales"). It is constructed from mandatory employer reports of their workers' characteristics. For every firm in France with at least one employee, we have information on the number of workers by year in each of five categories: $2=$ Firm owners receiving a wage; $3=$ Administrative and commercial managers (includes engineers); $4=$ Technicians and supervisors; $5=$ White Collar employees; $6=$ Production workers (Blue Collar). Categories are based on the French Nomenclature des professions et catégories socioprofessionnelles, PCS. ${ }^{18}$ We construct our main measure of skill intensity at the firm level as the fraction of non-production workers in total employment. The skill ratio of firm $f$ in year $t$ is

$$
\text { skill ratio } f t \equiv(2+3+4+5) /(6) \text {. }
$$

\section{Country- and Product-level Data}

We complement our firm-level dataset with the following information:

Country-level human-capital data: We use information on country-level skill abundance from Barro and Lee (2013) to construct the set of countries which are less skill abundant than France. Our measure of skill abundance is the number of years of secondary schooling in the population older than 15. We consider the set of countries that have less than 95 percent of the French level of secondary education (in the robustness checks in the Online Appendix we consider an 80-percent threshold). This information is available for the years 2000 and 2005; we use an average of the two data points. Table A-2 presents the set of countries. ${ }^{19}$

Product-level skill-intensity data: We use the NBER manufacturing database (Bartelsman and Gray, 1996; available at http://www.nber.org/nberces/) to construct measures of skill intensity

\footnotetext{
${ }^{18}$ The nomenclature underwent a change in 2003 . This change only affected the 3 -digit disaggregation, while the 1-digit classification we are using remained unchanged. Although this variable refers to occupations, it has often been used to proxy for the workers' skill level (e.g., Cahuc et al., 2006). Caliendo et al., forthcoming show that average wages are inversely linked to the position in the PCS.

${ }^{19}$ We exclude from the set of these countries any old EU-member countries that fall below these cutoffs. We do this for two reasons: first, because we do not consider these countries as truely labor-abundant, since they are all marginal cases; second, in the IV exercise we use EU external tariffs to construct our instrument, so we cannot include these countries. However, most of the empirical results are robust to including them in the set of labor-abundant countries. Those countries are: Belgium, Denmark, Finland, Greece, Ireland, Italy, Luxemburg, Portugal, Spain and the UK.
} 
at the product level. The data are available up to 2005. We define skill intensity as the ratio of non-production to production workers. Both measures are available at the NAICS97 6-digit level. We map them into HS6 codes using the concordance table provided by Pierce and Schott (2009). When more than one NAICS97 code maps into a single HS6 code, we take a simple average. The advantage of using U.S. industry data is that it is exogenous to events in France. To further avoid endogeneity issues, we use factor intensity in the pre-sample year 1995.

Tariff data: We employ information on EU external tariffs at the importer-product level to obtain exogenous variation in import flows. We use information on applied tariffs (simple averages) at the 6-digit HS level from the Worldbank's WITS database for our sample period.

World export data: We use data from the BACI database (administered by CEPII) to construct exports by HS 6-digit product for each country from which French firms import for the years 1996 to 2007 . We use this information to construct instrumental variables based on supply shocks in France's trading partners.

\section{Measuring the Average Skill Intensity of Imports}

The skill intensity of firm-level imports is a central measure to our analysis. It is constructed as follows. Denote the HS6 product-level skill intensity with skillint ${ }_{p}$, and the share of imports of product $p$ in firm $f$ 's total imports from labor-abundant countries in period $t$ as $w_{f, p, t}$. The average skill intensity of imports is defined as:

$$
\text { skill intensity } \text { ift }=\sum_{p \in I_{f, p, t}} \text { skillint }_{p} \times w_{f, p, t} .
$$

$s_{f, t}$ is a firm-level import-share-weighted average of factor intensities. $I_{f, p, t}$ is the set of products which firm $f$ imports from the set of labor-abundant countries in that period. We construct skillint $_{p}$ using the U.S. industry data described above. The definition of product-level skill intensity (the ratio of non-production to production workers) corresponds quite closely to our firm-level measure of skill intensity.

\section{Construction of Instrumental Variables}

In our empirical analysis we would like to exploit exogenous variation in offshoring. We thus need to construct instruments for the value of imports by firm from the set labor- and skill-abundant countries as well as for the average skill intensity of imports from labor-abundant countries. According to our model, changes in $\tau^{o}$ shift the offshoring threshold $z^{o}(\gamma)$ and thereby change 
both the value and the average skill intensity of imports from labor-abundant countries. Observe that changes in $\tau^{o}$ capture both changes in offshoring costs (including import tariffs) and foreign export supply shocks. Hence, we construct two types of instruments for the endogenous variables which exploit this variation.

Export supply shock instruments. The first set of instruments for imports is based on world export supply shocks, following recent work by Autor et al. (2013). These instruments are based on the following idea: an increase in world exports of product $p$ by country $c$ reflects a shock in country c's competitiveness for this product (due, for example, to exogenous variation in productivity, costs or product quality). French firms importing product $p$ from country $c$ would respond to this shock by increasing their imports of this product from this specific origin. Exogeneity is ensured by the fact that supply shocks in foreign countries are exogenous to firmlevel decisions in France. To construct such firm-specific instruments, we rely on Hummels et al. (2014). For each firm, we compute the share of each (HS6) product-country pair in total imports in the first year the firm appears in the sample in order to avoid endogeneity concerns and then take an import-share weighted average of foreign export supply shocks. Specifically, let $X_{p, c, t}$ be the export supply of product $p$ by country $c$ in period $t$ (excluding exports to France) and let $w_{f, p, c, 0}$ be the share of imports of product $p$ from country $c$ in firm $f^{\prime}$ 's imports from labor-abundant countries in the first period the firm is in the sample. Then the firm-specific instrument for the value of imports from labor-abundant countries is constructed as

$$
\text { imports }_{f, t, 1}=\sum_{c \in I_{f, c, 0}} \sum_{p \in I_{f, p, 0}} w_{f, p, c, 0} \times X_{p, c, t}
$$

where $I_{f, c, 0}$ and $I_{f, p, 0}$ is the set of countries and products a given firm imports in the first year it is in the sample. Observe that all the time variation in the instrument is due to exogenous export supply-shocks. Moreover, given that we use initial imports as weights, the instrument operates only through the intensive margin of imports. We construct an instrument for the value of imports from skill-abundant countries in an analogous way. In addition, we construct a supply-shock based instrument for the average skill intensity of imports from labor-abundant countries. This instrument is defined as an initial import-shares $\times$ supply-shock weighted average of product-level skill intensities.

$$
\text { skill intensity }_{f, t, 1}=\sum_{p \in I_{f, p, 0}} \text { skillint }_{p} \times\left(\sum_{c \in I_{f, c, 0}} w_{f, p, c, 0} \times X_{p, c, t}\right) .
$$


Again, all the time variation in the instrument arises from country-product-specific supply shocks. The quality of the instruments requires a firm-specific set of potential markets which is stable over time, two conditions that are met in our data. ${ }^{20}$

Tariff instrument. Our second type of instrument exploits tariff reductions from the Uruguay round of multilateral trade liberalization, which was concluded in 1994 and implemented up to the early 2000s. Tariff reductions should increase offshoring to labor-abundant countries and provides exogenous variation in imports from these countries. ${ }^{21}$

To construct a tariff-based instrument for the average skill intensity of imports from laborabundant countries, we first take a given set of firm-country-product pairs and regress the (log) value of imports of product $p$ from country $c$ of firm $f$ on the $\log$ of the applied EU external tariff $\log \left(\operatorname{tarif} f_{p, c, t}\right)$ as well as firm, product and country fixed effects: ${ }^{22}$

$$
\log (\text { imports })_{f, p, c, t}=\beta_{0}+\beta_{1} \log \left(\operatorname{tariff} f_{p, c, t}\right)+\delta_{f}+\delta_{p}+\delta_{c}+\epsilon_{f, p, c, t} .
$$

We then obtain predicted values from this regression, $\log \left(\right.$ import $\left._{f, p, c, t}\right)$ These are import values explained by firm, product and country means, as well as tariffs. Observe that, given that we hold the set of products and countries constant, all the time variation in predicted import values comes from changes in tariffs. Next, we sum predicted imports across countries to obtain firm-producttime specific weights $\hat{w}_{f, p, t}=\frac{\sum_{c} i_{m p o r} \hat{t}_{f, p, c, t}}{\sum_{p} \sum_{c} \text { import }_{f, p, c, t}}$. Finally, we multiply these with product-specific skill-intensities and sum over products to obtain the tariff-predicted average skill intensity of imports of a given firm in a given year:

$$
\text { skill intensity }_{f, t, 2}=\sum_{p \in I_{f, p, t}} \text { skillint }_{p} \times \hat{w}_{f, p, t} .
$$

\footnotetext{
${ }^{20}$ Carluccio et al. (2015) provide detailed evidence in favor of these points for the firms in our sample.

${ }^{21}$ As a result of multilateral trade negotiations, the European Union reduced its average applied most-favorednation tariffs in manufacturing by around 3 percentage points (see Finger et. al, 1996), with a lot of variation across products. Most of these tariff reductions were implemented in the late 1990s. Moreover, during the same period substantial bilateral tariff reductions with several Eastern European countries took place. This was a consequence of the association agreements predating their accession to the EU - Cyprus, the Czech Republic, Estonia, Hungary, Latvia, Lithuania, Malta, Poland, Slovakia and Slovenia became EU members in 2004, Bulgaria and Romania followed in 2007. Tariff reductions generally started in the early 1990s and were implemented in several steps until the early 2000s. Finally, the EU also signed several bilateral free trade agreements during our sample period which lead to further tariff reductions.

${ }^{22}$ The estimated coefficient of $\log \left(\operatorname{tarif} f_{p, c, t}\right)$ for the set of countries with less than 95 percent of the French level of secondary schooling is -0.029 and significant at the one-percent level, implying that a 100 percent higher tariff reduces imports of a given product by a given firm by around 2 percent.
} 


\section{Estimating Sample}

We restrict the sample to firms in manufacturing and we only consider imports of manufactured goods. ${ }^{23}$ The estimating sample so obtained is an unbalanced panel covering 1996 to 2007 with 646,920 firm/year observations corresponding to 104,036 firms. Of these, 13,343 import at least once from the set of countries with less than 95 percent of the French level of secondary schooling in the population. ${ }^{24}$ Table A-1 presents summary statistics of firm-level variables.

\section{Empirical Results}

In this section we present evidence for the empirical predictions derived from our model. We have already provided empirical evidence for Prediction 1 - which states that there is significant within-sector variation in firm-level skill ratios - in the section on descriptive statistics. We therefore start with testing Prediction 2.

\subsection{Empirical Predictions 2-5: Productivity, the Skill Intensity and the Origin of Imports}

Prediction 2 states that, for firms importing from labor-abundant countries, the average skill intensity of these imports should be increasing in firm-level productivity. The regression specification is as follows:

$$
\text { skill intensity } f, t=\beta_{0}+\beta_{1} \log (T F P)_{f, t-1}+\beta_{2} X_{f, t}+\epsilon_{f, t} .
$$

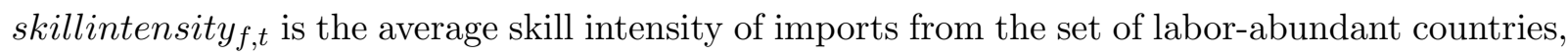
$\log (T F P)_{f, t-1}$ is the one-period lag of firm-level $\log$ TFP and $X_{f, t}$ is a vector of control variables, which - depending on the specification - includes either 4-digit sector fixed effects or firm fixed effects. We always include year fixed effects. In addition, to control for other factors that might be correlated both with the average skill intensity of imports and productivity, we add the number of employees, the capital/labor ratio, the value of exports and the value of imports (all in logs) in some specifications.

\footnotetext{
${ }^{23}$ We keep firms in the two-digit NACE Rev2 industries 10-33, with the exception of natural resource-based codes 12 (Manufacture of tobacco products) and 19 (Manufacture of coke and refined petroleum products). We exclude imports of raw materials (HS01-15, 23, 25-27, 31 and 41) and services (HS97-99). Excluded import flows account for around $5 \%$ of total imports over the period.

${ }^{24}$ To mitigate measurement error, we consider firms as importers when they import for at least two consecutive years.
} 
The results are reported in Table 3. In columns (1) and (2), we present results including 4-digit sector fixed effects, which exploit the cross-section variation of the data. By contrast, in columns (3) and (4), we focus on the within-firm variation by including firm fixed effects. We always cluster standard errors at the firm level. In all regressions, the coefficient of log TFP is positive and highly statistically significant, confirming our theoretical prediction. This result is robust to including further controls.

\begin{tabular}{|c|c|c|c|c|}
\hline \multicolumn{5}{|c|}{$\begin{array}{l}\text { Dependent variable is average skill intensity of imports } f t \\
\text { from countries } \leq 95 \text { percent of French sec. schooling }\end{array}$} \\
\hline & $(1)$ & $(3)$ & $(2)$ & $(4)$ \\
\hline $\log (\mathbf{T F P})_{f, t-1}$ & $\begin{array}{l}\mathbf{0 . 0 0 8 6} * * * \\
(0.001)\end{array}$ & $\begin{array}{l}\mathbf{0 . 0 0 5 2} * * * \\
(0.002)\end{array}$ & $\begin{array}{l}\mathbf{0 . 0 0 4 5 * * *} \\
\quad(0.002)\end{array}$ & $\begin{array}{l}\mathbf{0 . 0 0 3 7} * * \\
(0.002)\end{array}$ \\
\hline $\log (\text { employees })_{f, t}$ & & $\begin{array}{c}-0.0032^{* * *} \\
(0.001)\end{array}$ & & $\begin{array}{l}0.0027 \\
(0.002)\end{array}$ \\
\hline $\log (\text { capital/labor })_{f, t}$ & & $\begin{array}{l}0.0021^{* * *} \\
(0.001)\end{array}$ & & $\begin{array}{l}0.0021 \\
(0.002)\end{array}$ \\
\hline $\log (\text { exports })_{f, t}$ & & $\begin{array}{c}-0.0007^{* *} \\
(0.000)\end{array}$ & & 0.0005 \\
\hline $\log (\text { imports })_{f, t}$ & & $\begin{array}{c}0.0046 * * * \\
(0.001)\end{array}$ & & $\begin{array}{c}0.0017^{* *} \\
(0.001)\end{array}$ \\
\hline Observations & 55,333 & 55,333 & 55,333 & 55,333 \\
\hline Firms & 13,297 & 13,297 & 13,297 & 13,297 \\
\hline Firm FE & NO & NO & YES & YES \\
\hline 4-digit Sector FE & YES & YES & $\mathrm{NO}$ & $\mathrm{NO}$ \\
\hline Time FE & YES & YES & YES & YES \\
\hline Cluster & Firm & Firm & Firm & Firm \\
\hline R-squared & 0.3152 & 0.3183 & 0.0042 & 0.0046 \\
\hline
\end{tabular}

Table 3: Skill intensity of imports from labor-abundant countries and productivity

The dependent variable is the average skill intensity of imports from labor-abundant countries at the firm level (see the data section for an explanation of the construction of this variable). We consider imports from countries with less than 95 percent of the French level of secondary schooling. The main explanatory variable of interest is the one-year lag of firm-level productivity computed with the Levinsohn-Petrin method, $\log (T F P)_{f, t}$. Other controls are (all at the firm level and in logs): the number of employees, the capital-labor ratio and the value of exports and imports.

Next, we investigate the precise microeconomic channels that lead to the positive correlation between firm-level productivity and the average skill intensity of firms' imports from laborabundant countries. In particular, our model predicts that, when considering importers from a specific labor-abundant country, more productive firms should import a more skill-intensive mix of products from that country compared to less productive ones (Prediction 3, Part 1). To test this hypothesis, we run the following gravity regression:

$$
\begin{aligned}
\log \left(\text { imports }_{f, p, c, t}\right. & =\beta_{0}+\beta_{1} \log (\text { TFP })_{f, t}+\beta_{2} \text { skillint }_{p}+ \\
& +\beta_{3} \log (\text { TFP })_{f, t} * \text { skillint }_{p}+\beta_{4} X_{f, c, t}+\epsilon_{f, p, c, t},
\end{aligned}
$$

where $\log (\text { imports })_{f, p, c, t}$ is the $(\log )$ import value of product $p$ from country $c$ by firm $f$ in 
year $t, \log (T F P)_{f, t}$ is $\log$ TFP, skillint $p$ is the skill intensity of product $p$ and the vector $X_{f, c, t}$ always includes country and year fixed effects. Depending on the specification, it also includes employment, the capital-labor ratio and the value of exports (all in logs). Observe that, by including country and year fixed effects, we exploit the within-country, cross-section variation across firms and products.

We expect the coefficient on skill intensity, $\beta_{2}$, to be negative, since the comparative advantage of labor-abundant countries is in labor-intensive sectors. More importantly, we expect $\beta_{3}$, the interaction term between product-level skill intensity and firm-level TFP, to be positive. We report the results for these regressions in the first two columns of Table 4. As expected, in both specifications, the coefficient on skill intensity is negative, while the interaction term between product-level skill intensity and log TFP is positive and statistically highly significant. This confirms the hypothesis that more productive firms import more skill-intensive products from a given labor-abundant country.

Our theory also predicts that all firms offshoring to those countries should import the relatively labor-intensive products. We thus expect more productive importers to have a larger variation in the skill intensity of the products that they import from a given country (Prediction 3, part 2 ). In order to test this prediction, we compute for each firm the dispersion of the skill intensity of its imports from any given labor-abundant country.

As our measure of skill dispersion, we consider the ratio of the 75 th to the 25 th percentile of skill intensity of products imported by a given firm from a given country. ${ }^{25}$ We then regress this measure of skill dispersion on firm-level productivity (averaged over all years the firm is in the sample). The regression specification is:

$$
\text { dispersion }_{f, c}=\beta_{0}+\beta_{1} \log (T F P)_{f}+\beta_{2} X_{f, c}+\epsilon_{f, c} .
$$

Here, the vector of controls includes our standard set of firm-level controls (averaged over periods) and the number of products a given firm imports from a given country (in logs). We include the last variable in order to avoid any confusion with the mechanical result that firms sampling more products randomly from a given country will have a larger dispersion in the skill intensity of their sampled products. Results are reported in the first two columns of Table 5. In all specifications, the coefficient of $\log (\mathrm{TFP})$ enters positively and is strongly statistically significant, which is

\footnotetext{
${ }^{25}$ Using other measures of dispersion, such as the standard deviation or the ratio of the 90th to the 10th percentile gives very similar results.
} 
consistent with our hypothesis.

We now turn to the next theoretical prediction. Prediction 4 states that out of the set of labor-abundant countries, only sufficiently productive firms will find it profitable to import not only from the very labor-abundant countries but also from the relatively more skill-abundant ones. To test this prediction, we change the specification of our gravity regression as follows:

$$
\begin{aligned}
\log \left(\text { imports }_{f, p, c, t}\right. & =\beta_{0}+\beta_{1} \log (T F P)_{f, t}+\beta_{2} \text { sec.schooling }+ \\
& +\beta_{3} \log (T F P)_{f, t} * \text { sec.schooling } \\
+ & \beta_{4} X_{f, c, t}+\epsilon_{f, p, c, t}
\end{aligned}
$$

where sec.schooling is the skill abundance (measured in terms of years of secondary schooling) of country $c$ relative to France and where the vector $X_{f, c, t}$ always includes year fixed effects. Depending on the specification, it also includes our standard set of firm-specific controls and a set of country-specific gravity controls (distance from France, GDP, GDP per capita, area (all in logs), dummies for common language, common border, colony).

We expect the coefficient of sec.schooling $g_{c}, \beta_{2}$, to enter negatively - since cost advantages of importing from relatively more skill-abundant countries are smaller. Moreover, we expect the interaction term between sec.schooling $g_{c}$ and $\log (T F P)_{f, t}, \beta_{3}$, to have a positive coefficient, since only sufficiently productive firms will import from more skill-abundant countries. Results for this specification are reported in columns (3) and (4) of Table 4. In both specifications, sec.schooling enters negatively and is statistically strongly significant. More importantly, the interaction term between sec.schooling $g_{c}$ and $\log (T F P)_{f, t}$ is always positive and mostly highly significant. This confirms our theoretical prediction that out of the set of labor-abundant countries, more productive firms import from more skill-abundant ones.

The second part of Prediction 4 states that more productive firms should have more variation in the skill abundance of countries from which they import compared to less productive ones. As our measure of skill-abundance dispersion, we consider the ratio of the 75 th to the 25 th percentile of skill abundance of those countries from which a given firm imports (out of the set of laborabundant countries). We then regress this measure of skill-abundance dispersion on firm-level productivity (averaged over all years the firm is in the sample). The regression specification is:

$$
\text { dispersion }_{f}=\beta_{0}+\beta_{1} \log (T F P)_{f}+\beta_{2} X_{f}+\epsilon_{f}
$$


Here, the vector $X_{f}$ includes our standard set of firm-level controls (averaged over periods) as well as the number of countries from which a given firm imports (in logs). We include the last variable in order to avoid any confusion with the purely mechanical result that firms sampling more countries randomly have a larger dispersion in skill abundance of their sampled countries. Results are reported in columns (3) and (4) of Table 5. In all specifications, the coefficient of $\log (\mathrm{TFP})$ enters positively and is strongly statistically significant, which is consistent with our hypothesis.

Finally, we turn to the results on complementarity of import decisions across source countries. Prediction 5 states that for importers from the set of labor-abundant countries - holding constant productivity - firms importing more labor-intensive products from other source countries import more from a given country. Moreover, firms importing from a more labor-abundant mix of source countries import more from a given country. To test these predictions, for each firm-productcountry we compute the skill intensity of imports of other products from other labor-abundant countries (measured as a simple average) and the skill-abundance of the other import origin countries (measured again as a simple average over the levels of secondary schooling). ${ }^{26}$ We then consider the following regression specifications:

$$
\begin{aligned}
& \log \left(\text { imports }_{f, p, c, t}\right.=\beta_{0}+\beta_{1} \log (\text { TFP })_{f, t}+\beta_{2} \text { skillint }_{p}+\beta_{3} \log (\text { TFP })_{f, t} * \text { skillint }_{p}+ \\
&+\beta_{4} \text { skillint other products } f, p, t \\
&+\beta_{5} X_{f, c, t}+\epsilon_{f, p, c, t}
\end{aligned}
$$

where $X_{f, c, t}$ contains the total number of other imported products, our usual set of firm-specific controls, country and year fixed effects and

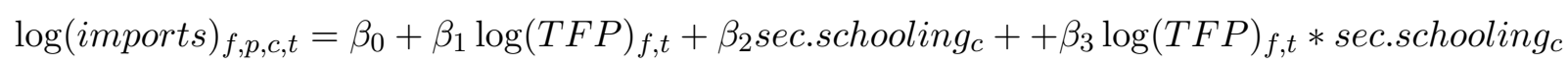

$$
+\beta_{4} \text { sec. schooling other countries } f, c, t+\beta_{5} X_{f, c, t}+\epsilon_{f, p, c, t},
$$

where $X_{f, c, t}$ contains the total number of other source countries, our usual set of firm-specific controls, year fixed effects, as well as bilateral gravity controls. In both specifications, we expect $\beta_{4}$ to be negative, indicating that firms importing a set of more skill-intensive (other) products or

\footnotetext{
${ }^{26}$ Results are robust to considering instead an import share-weighted average of skill intensity or skill abundance.
} 
from more skill-abundant (other) countries import less from a given country of origin compared to firms importing relatively more labor-intensive products or from labor-abundant countries. The results are presented in columns (5)-(8) of Table 4 . In all cases, $\beta_{4}$ has the expected negative sign and is highly statistically significant, while the other coefficients remain unaffected by the inclusion of the new variables. We thus conclude that there is strong evidence for complementarities across sourcing countries, with cost reductions being larger for imports of labor-intensive products and imports originating in labor-abundant countries. ${ }^{27}$

The above results have focused on the specific hypotheses regarding import behavior from labor-abundant countries and productivity. We have shown that the predicted relationships between product-level skill intensity, country-level skill abundance and productivity hold in the data. Next, we show that importing from labor-abundant countries is also associated with significantly higher skill ratios of production in France.

\footnotetext{
${ }^{27}$ Since one may be concerned that firm productivity is endogenous to import decisions, in unreported regressions we consider TFP in the initial period instead of contemporaneous values. We find that all the results for predictions 3-5 are robust to this change.
} 


\begin{tabular}{|c|c|c|c|c|c|c|c|c|}
\hline \multicolumn{9}{|c|}{ dependent variable is $\log (\text { imports })_{f, p, c, t}$} \\
\hline & $(1)$ & $(2)$ & (3) & (4) & $(5)$ & (6) & $(7)$ & $(8)$ \\
\hline $\log (\mathrm{TFP})_{f, t}$ & $\begin{array}{c}-0.6285^{* * *} \\
(0.075)\end{array}$ & $\begin{array}{c}-0.6759^{* * *} \\
(0.069)\end{array}$ & $\begin{array}{c}-0.5258^{* * *} \\
(0.062)\end{array}$ & $\begin{array}{c}-0.6665^{* * *} \\
(0.068)\end{array}$ & $\begin{array}{c}-0.5703^{* * *} \\
(0.069)\end{array}$ & $\begin{array}{c}-0.5715^{* * *} \\
(0.065)\end{array}$ & $\begin{array}{c}-0.5132^{* * *} \\
(0.061)\end{array}$ & $\begin{array}{c}-0.6061^{* * *} \\
(0.067)\end{array}$ \\
\hline skill intensity $p$ & $\begin{array}{c}-4.6065^{* * *} \\
(0.933)\end{array}$ & $\begin{array}{c}-4.0837^{* * *} \\
(0.840)\end{array}$ & & & $\begin{array}{c}-4.6329^{* * *} \\
(0.978)\end{array}$ & $\begin{array}{c}-3.3129^{* * *} \\
(0.876)\end{array}$ & & \\
\hline $\begin{array}{l}\log (\mathrm{TFP})_{f, t} \\
\text { skill intensity }\end{array}$ & $\begin{array}{c}1.1818^{* * *} \\
(0.244)\end{array}$ & $\begin{array}{c}0.8979 * * * \\
(0.220)\end{array}$ & & & $\begin{array}{c}1.2176^{* * *} \\
(0.257)\end{array}$ & $\begin{array}{c}0.7898^{* * * *} \\
(0.228)\end{array}$ & & \\
\hline sec. schooling $c$ & & & $\begin{array}{c}-1.9766^{* * *} \\
(0.549)\end{array}$ & $\begin{array}{c}-1.3182^{* *} \\
(0.615)\end{array}$ & & & $\begin{array}{c}-2.1721^{* * *} \\
(0.571)\end{array}$ & $\begin{array}{c}-1.4817^{* *} \\
(0.622)\end{array}$ \\
\hline $\log (\mathbf{T F P})_{f, t} *$ & & & $0.2956^{* *}$ & $0.3268^{*}$ & & & $0.3356^{* *}$ & $0.3444^{* *}$ \\
\hline sec. schooling $_{c}$ & & & $(0.150)$ & $(0.169)$ & & & $(0.154)$ & $(0.170)$ \\
\hline skill intensity other products pr,p,t $_{f}$ & & & & & $\begin{array}{c}-0.5934^{* *} \\
(0.285)\end{array}$ & $\begin{array}{l}-1.7194^{* * *} \\
(0.286)\end{array}$ & & \\
\hline sec. schooling other countries $f, c, t$ & & & & & & & $\begin{array}{c}-0.6033^{* * *} \\
(0.106)\end{array}$ & $\begin{array}{c}-0.9823^{* * *} \\
\quad(0.106)\end{array}$ \\
\hline $\log (\text { employees })_{f, t}$ & & $\begin{array}{c}0.0733^{* *} \\
(0.032)\end{array}$ & & $\begin{array}{c}0.0739^{* *} \\
(0.031)\end{array}$ & & $\begin{array}{c}0.1601^{* * *} \\
(0.024)\end{array}$ & & $\begin{array}{c}0.1732^{* * *} \\
(0.031)\end{array}$ \\
\hline $\log (\text { capital/labor })_{f, t}$ & & $\begin{array}{c}0.0950^{* * *} \\
(0.032)\end{array}$ & & $\begin{array}{c}0.1079^{* * *} \\
(0.033)\end{array}$ & & $\begin{array}{c}0.0751^{* *} \\
(0.037)\end{array}$ & & $\begin{array}{c}0.0850^{* *} \\
(0.036)\end{array}$ \\
\hline $\log (\text { exports })_{f, t}$ & & $\begin{array}{c}0.2390^{* * * *} \\
(0.015)\end{array}$ & & $\begin{array}{c}0.2310^{* * * *} \\
(0.015)\end{array}$ & & $\begin{array}{c}0.2332^{* * * *} \\
(0.013)\end{array}$ & & $\begin{array}{c}0.2413^{* * *} \\
(0.017)\end{array}$ \\
\hline$\# \operatorname{products}_{f, t}$ & & & & & $\begin{array}{c}-0.0022 \\
(0.002)\end{array}$ & $\begin{array}{c}-0.0049^{* *} \\
(0.002)\end{array}$ & & \\
\hline$\# \operatorname{countries}_{f, t}$ & & & & & & & $\begin{array}{l}-0.0044 \\
(0.008)\end{array}$ & $\begin{array}{c}-0.0294^{* * *} \\
(0.010)\end{array}$ \\
\hline Observations & 666,427 & 666,427 & 683,820 & 605,261 & 649,483 & 649,483 & 628,637 & 553,897 \\
\hline Country FE & YES & YES & NO & $\mathrm{NO}$ & YES & YES & NO & NO \\
\hline Time FE & YES & YES & YES & YES & YES & YES & YES & YES \\
\hline Gravity Controls & NO & NO & NO & YES & $\mathrm{NO}$ & NO & NO & YES \\
\hline Cluster & Firm & Firm & Firm & Firm & Firm & Firm & Firm & Firm \\
\hline R-squared & 0.0096 & 0.0399 & 0.0219 & 0.0534 & 0.0116 & 0.0492 & 0.0238 & 0.0633 \\
\hline Observations & 666,427 & 666,427 & 683,820 & 605,261 & 649,483 & 649,483 & 628,637 & 553,897 \\
\hline R-squared & 0.0096 & 0.0399 & 0.0219 & 0.0534 & 0.0116 & 0.0492 & 0.0238 & 0.0633 \\
\hline
\end{tabular}

Table 4: Imports from labor-abundant countries and skill-intensity/skill-abundance interactions with productivity

The dependent variable is log imports from labor-abundant countries at the firm-product-country-year level. We consider imports from countries with less than 95 percent of the French level of secondary schooling. The main explanatory variable of interest in columns (1)-(2) is the interaction between product-level skill intensity (skill intensity $y_{p}$ ) and firm-level productivity computed with the Levinsohn-Petrin method $\left(\log (T F P)_{f, t}\right)$. The main explanatory variable of interest in columns (3)-(4) is the interaction between country-level skill abundance (sec. schooling $\left.g_{c}\right)$ and firm-level productivity $\left(\log (T F P)_{f, t}\right)$. The main variable of interest in columns (5)-(6) is the skill-intensity of products imported from other destinations. The main variable of interest in columns (7)-(8) is the skill abundance of the other source countries. Other controls are (all at the firm level and in logs): the number of employees, the capital-labor ratio, the value of exports, the number of products a given firm imports, the number of countries from which a given firm imports. Some specifications also include gravity controls (GDP, GDP per capita, distance, area, dummies for border common language, colony). 


\begin{tabular}{|c|c|c|c|c|}
\hline $\begin{array}{r}\text { depen } \\
\text { coun } \\
\end{array}$ & $\begin{array}{l}\text { nt variable is } \\
\text { product ski } \\
\text { ies } \leq 95 \text { perc }\end{array}$ & $\begin{array}{l}5 \text { th } / 25 \text { th pe } \\
\text { intensity } f, c \\
\text { it of French }\end{array}$ & $\begin{array}{l}\text { entile ratio of } \\
\text { country skil } \\
\text { c. schooling }\end{array}$ & abundance $_{f}$ \\
\hline & $(1)$ & $(2)$ & $(3)$ & $(4)$ \\
\hline $\log (\mathbf{T F P})_{f}$ & $\begin{array}{c}\mathbf{0 . 0 1 7 2}^{* * * *} \\
(0.002)\end{array}$ & $\begin{array}{c}\mathbf{0 . 0 5 7 7} * * * \\
(0.004)\end{array}$ & $\begin{array}{c}\mathbf{0 . 0 8 5 8} * * * \\
(0.014)\end{array}$ & $\begin{array}{c}\mathbf{0 . 0 4 5 9}^{* * * *} \\
(0.003)\end{array}$ \\
\hline $\log (\text { employees })_{f}$ & & $\begin{array}{c}0.0168^{* * *} \\
(0.002)\end{array}$ & & $\begin{array}{c}0.0110 * * * \\
(0.001)\end{array}$ \\
\hline $\log (\text { capital/labor })_{f}$ & & $\begin{array}{c}-0.0203^{* * *} \\
(0.003)\end{array}$ & & $\begin{array}{c}0.0316^{* * *} \\
(0.001)\end{array}$ \\
\hline $\log (\text { exports })_{f}$ & & $\begin{array}{c}0.0079 * * * \\
(0.001)\end{array}$ & & $\begin{array}{c}-0.0133^{* * *} \\
(0.001)\end{array}$ \\
\hline $\log (\# \text { products })_{f, c}$ & & $\begin{array}{c}0.0398 * * * \\
(0.003)\end{array}$ & & \\
\hline $\log (\# \text { countries })_{f}$ & & & & $\begin{array}{c}0.0893^{* * *} \\
(0.002)\end{array}$ \\
\hline Observations & 91,919 & 91,919 & 23,243 & 23,243 \\
\hline R-squared & 0.0015 & 0.0294 & 0.1980 & 0.2250 \\
\hline Robust s.e. & YES & YES & YES & YES \\
\hline
\end{tabular}

Table 5: Dispersion of product skill intensity/country skill-abundance and firm-level productivity The dependent variable is the ratio of 75 th to the 25 th percentile of product-level skill intensity by import country and firm (in columns (1)-(2)) and the ratio of the 75th to the 25th percentile of the exporting countries' secondary schooling endowments by firm (in columns (3)-(4)). We consider imports from countries with less than 95 percent of the French level of secondary schooling. The main explanatory variable of interest is log firm-level productivity averaged over the sample period computed with the Levinsohn-Petrin method $\left(\log (T F P)_{f}\right)$. Other controls are (all at the firm level and in logs): the number of employees, the capital-labor ratio, the value of exports, the total number of products imported from a given country and the number of countries from which a given firm imports.

\subsection{Empirical Predictions 6 and 7: Imports and the Skill Ratio of Production in France}

Prediction 6 states that importers from labor-abundant countries are more skill intensive in their production in France compared to other firms (French non-importers and importers from skillabundant countries). The regression specification is:

$$
\begin{aligned}
\log \left(\text { skillratio }_{f, t}\right. & =\beta_{0}+\beta_{1}{\text { Imports Below } \text { Threshold }_{f, t}+} \\
& +\beta_{2} \text { Imports Above Threshold }_{f, t}+\beta_{3} X_{f, t}+\epsilon_{f, t}
\end{aligned}
$$

where Imports Below Threshold $_{f, t}$ is either a dummy for importing from the set of labor-abundant countries (extensive margin) or the ratio of imports from labor-abundant countries relative to total sales (intensive margin). Similarly, Imports Above Threshold $f_{f, t}$ is either a dummy for importing from the set of skill-abundant countries, or the ratio of imports from skill-abundant countries to total sales. The vector $X_{f, t}$ includes either 4-digit sector or firm fixed effects, as well as year fixed effects. Depending on the specification, it also includes employment, the capital-labor ratio (all in logs) and controls for exporting. 
We present results for the extensive margin in the first four columns of Table 6 . The dummy for importing from labor-abundant countries captures the relative skill ratio of production in France of importers from labor-abundant countries compared to non-importers. In columns (1) and (2), we report specifications including 4-digit sector fixed effects, so these specifications use the cross-section variation in the data. Importers from labor-abundant countries are around 22 percent $^{28}$ (column (1)) to 28.3 percent (column (2)) more skill-intensive in their production in France than non-importers and this effect is statistically highly significant. This contrasts with importers from skill-abundant countries, which are only marginally different from non-importers in terms of their skill ratios (around 3.6 percent less skill-intensive (column (1))). ${ }^{29}$ In columns (3) and (4), we report results including firm fixed effects, thereby identifying the dummies for importing via within-firm changes in import status: the result in column (3) indicates that firms that start importing from labor-abundant countries simultaneously increase their skill ratio by around 4 percent, while those that start importing from skill-abundant countries decrease it slightly (by around 1.2 percent). Observe that all results are robust to controlling for TFP, the capital-labor ratio and the export status. Focusing on the within-firm results, exporting has a significantly positive effect on the skill ratio of production, while TFP has a small negative effect conditional on firms' import status from labor-abundant countries. ${ }^{30}$

We now consider instead the intensive margin of imports, and define our regressor of interest as firms' imports from the set of labor-abundant countries normalized by sales. We do this in order to avoid a downward bias in our estimates since the import dummy also includes firms that are only marginal importers. Moreover, according to our theoretical model, an increase in imports over sales should lead to an increase in the domestic skill ratio. Again, in order to allow for a differential effect of importing from skill-abundant countries, we include as a separate regressor firm-level imports from skill-abundant countries normalized by sales. Results are reported in columns (5)-(8) of Table 6. In columns (5) and (6) we include all firms (including non-importers), while in columns (7) and (8) we restrict the sample to importers from both sets of countries. For the sake of space, we only present specifications including firm and year fixed effects. The result in column (5) indicates that a one-unit increase in the ratio of imports from

\footnotetext{
${ }^{28} 22=100 *(\exp (0.1996)-1)$

${ }^{29}$ Observe that while at first glance this result seems to be add odds with our model, which predicts that firms importing from more skill-abundant countries are more labor-intensive than non-importers, this is actually not the case: within the set of skill-abundant countries, France has roughly the average skill abundance and the most skill-abundant countries have a level of secondary schooling which is only 1.2 times larger than that of France. Thus, one would not expect importing from these countries to have a large negative effect on the skill ratio of their domestic production.

${ }^{30}$ Note that the unconditional within-firm correlation between TFP and the log skill ratio is positive.
} 
labor-abundant countries relative to sales increases the skill ratio of production in France by around 25 percent and is highly significant. This effect contrasts with the impact of importing from skill-abundant countries, where a one-unit increase in the imports-to-sales ratio reduces the firm-level skill ratio by a comparatively much smaller and insignificant 0.86 percent. Finally, the results for the sample of importers (columns (5)-(8)) are very similar to those obtained for the full sample of firms. We conclude that there is strong evidence that importing from labor-abundant countries is associated with large increases in the skill ratio of production in France. ${ }^{31}$

\section{Instrumental Variable Estimates}

Finally, we turn to the instrumental variables results. We need to instrument both for imports/sales from labor-abundant and from skill-abundant countries. We thus use supply-shock instruments to obtain exogenous variation in imports. ${ }^{32}$ Since the supply shock instruments provide exogenous time variation in imports for a given firm, we report results for the 2-stageleast-square regressions with firm and year fixed effects for the sample of importers in Table 7.

Focusing first on the first-stage regressions, we find that the shocks have the expected signs and are significant at the one-percent level. The Angrist-Pischke F-statistic is always above 13 for the first-stage regressions with imports/sales below the threshold as dependent variable and above 10 when imports/sales above the threshold is instrumented, indicating that weak instruments are not a problem. Turning now to the second-stage results, the point estimate for the coefficient for importing from labor-abundant countries is now 5.51 (compared to 0.25 for the OLS estimator). This large increase in the magnitude of the coefficient is likely due to measurement error in the time variation of imports, which biases fixed effects results towards zero. ${ }^{33}$ The coefficient for imports from skill-abundant countries is instead negative and also large (-4.28 compared to -0.009 for the OLS estimator) and now it is also statistically significant. These results are robust to adding the standard set of controls. The IV estimates imply large economic effects of importing from labor-abundant countries. For the estimating sample, the average skill ratio changed by around $0.86 \log$ points between 1996 and 2007. Evaluating the estimates for the effect

\footnotetext{
${ }^{31}$ In unreported regressions we have also regressed the employment of skilled and unskilled workers separately on imports relative to sales from labor-abundant countries. Within-firm results indicate that firms which increase imports from labor-abundant countries reduce blue-collar employment and increase employment of skilled workers. Moreover, as our model suggests, these firms simultaneously increase their sales.

${ }^{32}$ Unfortunately, we cannot construct tariff-based instruments for imports because the set of skill-abundant countries consist mostly of EU members, which have no tariff barriers vis-à-vis France.

${ }^{33}$ Hummels et al. (2014) find a similar increase in the magnitude of their point estimates when instrumenting for the effect of offshoring on wages of Danish workers using supply shocks.
} 
of importing from labor-abundant countries at the mean of imports/sales below the threshold, we find that the skill ratio should have changed by around $0.093 \log$ points, which corresponds to slightly more than the total actual change in the log skill ratio. ${ }^{34}$ Thus, offshoring to laborabundant countries can potentially explain the bulk of the observed within-firm increase in the skill ratio of importers.

We now turn to the last theoretical prediction of our model. Prediction 7 states that the average skill intensity of imports from the set of labor-abundant countries should be positively correlated with the skill ratio of firms' production in France. We thus regress the (log) skill ratio of firms' production on the average skill intensity of their imports from labor-abundant countries. We focus on the following empirical specification:

$$
\log \left(\text { skillratio }_{f, t}=\beta_{0}+\beta_{1} \text { skill intensity } \text { int }+\beta_{2} X_{f, t}+\epsilon_{f, t},\right.
$$

where skill intensity f $_{, t}$ is the average skill intensity of imports from the set of labor-abundant countries and $X_{f, t}$ is our vector of standard controls (sector or firm and year fixed effects as well as employment, the capital-labor ratio, the value of imports and the value of exports (all in logs).)

The results for this specification are presented in columns (1)-(4) of Table 8. In columns (1) and (2), we report results for a specification including 4-digit sector-fixed effects. The result in column (1) indicates that a one-unit increase in the average skill intensity of imports is associated with a 46-percent increase in the skill ratio and is highly significant. Adding further controls in column (2) leaves the results unaffected.

\footnotetext{
${ }^{34}$ Average imports/sales from countries below the 95 percent threshold increased from 0.053 to 0.07 from 1996 to 2007 , thus the effect is given by $5.51 *(0.07-0.053)=0.093$.
} 


\begin{tabular}{|c|c|c|c|c|c|c|c|c|}
\hline \multicolumn{9}{|c|}{ dependent variable is $\log (\text { skill ratio })_{f t}$; countries $\leq 95$ percent of French sec. schooling } \\
\hline & $(1)$ & $(2)$ & $(3)$ & $(4)$ & $(5)$ & $(6)$ & $(7)$ & $(8)$ \\
\hline import status & $0.1996 * * *$ & $0.2497 * * *$ & $0.0388 * * *$ & $0.0437 * * *$ & & & & \\
\hline below threshold $_{f, t}$ & $(0.009)$ & $(0.009)$ & $(0.004)$ & $(0.004)$ & & & & \\
\hline imports/sales & & & & & $0.2500 * * *$ & $0.2352 * * *$ & $0.2152^{* *}$ & $0.1697^{* *}$ \\
\hline $\begin{array}{l}\text { below threshold } f, t \\
\text { import status }\end{array}$ & $-0.0349 * * *$ & -0.0034 & $-0.0124^{* * *}$ & 0.0024 & & & & \\
\hline above threshold $f, t$ & $(0.006)$ & $(0.006)$ & $(0.003)$ & $(0.003)$ & & & & \\
\hline imports/sales & & & & & -0.0086 & -0.0083 & -0.0231 & $-0.0346^{* *}$ \\
\hline above threshold $f, t$ & & & & & $(0.006)$ & $(0.006)$ & $(0.016)$ & $(0.017)$ \\
\hline $\log (\mathrm{TFP})_{f, t}$ & & $\begin{array}{c}0.3919 * * * \\
(0.006)\end{array}$ & & $\begin{array}{c}-0.0112^{* * *} \\
(0.004)\end{array}$ & & $\begin{array}{c}-0.0124^{* * *} \\
(0.004)\end{array}$ & & $\begin{array}{c}0.0048 \\
(0.011)\end{array}$ \\
\hline $\log (\text { employees })_{f, t}$ & & $\begin{array}{c}-0.1805^{* * *} \\
(0.003)\end{array}$ & & $\begin{array}{c}-0.1709^{* * *} \\
(0.005)\end{array}$ & & $\begin{array}{c}-0.1721^{* * *} * \\
(0.005)\end{array}$ & & $\begin{array}{c}-0.2365^{* * *} \\
(0.024)\end{array}$ \\
\hline $\log (\text { capital/labor })_{f, t}$ & & $\begin{array}{c}0.0235^{* * *} \\
(0.003)\end{array}$ & & $\begin{array}{c}-0.0183^{* * *} \\
(0.004)\end{array}$ & & $\begin{array}{c}-0.0186^{* * *} \\
(0.004)\end{array}$ & & $\begin{array}{c}-0.0481^{* * *} \\
(0.016)\end{array}$ \\
\hline $\operatorname{export}_{\text {status } f, t}$ & & $\begin{array}{c}0.1386^{* * *} \\
(0.006)\end{array}$ & & $\begin{array}{c}0.0157^{* * *} \\
(0.003)\end{array}$ & & & & \\
\hline $\log (\text { exports })_{f, t}$ & & & & & & $\begin{array}{c}0.0077^{* * *} \\
(0.001)\end{array}$ & & $\begin{array}{c}0.0107^{* * *} \\
(0.004)\end{array}$ \\
\hline Observations & 646,920 & 646,920 & 646,920 & 646,920 & 646,920 & 646,920 & 55,719 & 55,719 \\
\hline Firms & 104,036 & 104,036 & 104,036 & 104,036 & 104,036 & 104,036 & 12,714 & 12,714 \\
\hline Sample & all & all & all & all & all & all & importers & importers \\
\hline Firm FE & NO & NO & YES & YES & YES & YES & YES & YES \\
\hline 4-digit sector FE & YES & YES & NO & $\mathrm{NO}$ & NO & NO & NO & NO \\
\hline Time FE & YES & YES & YES & YES & YES & YES & YES & YES \\
\hline Cluster & Firm & Firm & Firm & Firm & Firm & Firm & Firm & Firm \\
\hline R-squared & 0.2039 & 0.2510 & 0.0040 & 0.0111 & 0.0042 & 0.0114 & 0.0465 & 0.0612 \\
\hline
\end{tabular}

Table 6: Skill ratio of production and importing from labor-abundant countries (extensive and intensive margin).

The dependent variable is the firm-level $(\log )$ skill ratio of production, defined as the ratio of non-production workers to production workers. We consider imports from countries with less than 95 percent of the French level of secondary schooling. In columns (1)-(4), the main explanatory variable of interest is a dummy for importing from the set of labor-abundant countries (import status below threshold). The specifications also include a dummy for importing from the set of skillabundant countries (import status above threshold). In columns (5)-(8), the main explanatory variable of interest is the ratio of imports from set of labor-abundant countries relative to sales (import/sales below threshold). The specifications also include the ratio of imports from the set of skill-abundant countries relative to sales (imports/sales above threshold). Other controls are (all at the firm level and in logs): TFP (constructed with the Levinsohn-Petrin method), the number of employees, the capital-labor ratio and the value of exports. 


\begin{tabular}{|c|c|c|c|c|c|c|c|}
\hline \multirow[t]{2}{*}{ First Stage } & \multicolumn{2}{|c|}{$\begin{array}{l}\text { Dep. var.: imports/sales } \\
\text { below threshold } \\
f, t\end{array}$} & \multicolumn{2}{|c|}{$\begin{array}{l}\text { Dep. var.: imports/sales } \\
\text { above threshold } \\
f, t\end{array}$} & \multirow[t]{2}{*}{ Second Stage } & \multicolumn{2}{|c|}{ Dep. var.: $\log (\text { skill ratio })_{f, t}$} \\
\hline & (1) & $(2)$ & (3) & $(4)$ & & (5) & (6) \\
\hline IV Supply Shock (below) & $\begin{array}{c}0.0026^{* * *} \\
(0.0008)\end{array}$ & $\begin{array}{c}0.0024^{* * *} \\
(0.0008)\end{array}$ & $\begin{array}{l}0.0027^{*} \\
(0.0016)\end{array}$ & $\begin{array}{c}0.0024 \\
(0.0016)\end{array}$ & imports/sales (below) & $\begin{array}{c}5.5135^{* *} \\
(2.760)\end{array}$ & $\begin{array}{l}4.8961^{*} \\
(2.704)\end{array}$ \\
\hline IV Supply Shock (above) & $\begin{array}{l}-0.0053^{*} \\
(0.0029)\end{array}$ & $\begin{array}{l}-0.0049^{*} \\
(0.0029)\end{array}$ & $\begin{array}{l}0.0066^{* *} \\
(0.0027)\end{array}$ & $\begin{array}{r}0.0065^{* *} \\
(0.0027)\end{array}$ & imports/sales (above) & $\begin{array}{c}-4.2816^{*} \\
(2.376)\end{array}$ & $\begin{array}{r}-3.7129 \\
(2.279)\end{array}$ \\
\hline $\log (\mathrm{TFP})_{f, t}$ & & $\begin{array}{c}-0.0081^{* * *} \\
(0.0022)\end{array}$ & & $\begin{array}{c}-0.0135^{* * *} \\
(0.0029)\end{array}$ & $\log (\mathrm{TFP})_{f, t}$ & & $\begin{array}{r}-0.0057 \\
(0.040)\end{array}$ \\
\hline $\log (\text { employees })_{f, t}$ & & $\begin{array}{c}-0.0270^{* * * *} \\
(0.0032)\end{array}$ & & $\begin{array}{c}-0.0174^{* * *} \\
(0.0059)\end{array}$ & $\log (\text { employees })_{f, t}$ & & $\begin{array}{c}-0.1696^{* *} \\
(0.086)\end{array}$ \\
\hline $\log (\text { capital/labor })_{f, t}$ & & $\begin{array}{l}-0.0031 \\
(0.0026)\end{array}$ & & $\begin{array}{c}0.0037 \\
(0.0028)\end{array}$ & $\log (\text { capital/labor })_{f, t}$ & & $\begin{array}{r}-0.0186 \\
(0.025)\end{array}$ \\
\hline $\log (\text { exports })_{f, t}$ & & $\begin{array}{c}0.0087^{* * *} \\
(0.0006)\end{array}$ & & $\begin{array}{c}0.0099^{* * *} \\
(0.0008)\end{array}$ & $\log (\text { exports })_{f, t}$ & & $\begin{array}{l}0.0064 \\
(0.034)\end{array}$ \\
\hline F-statistic (Angrist-Pischke) & 15,32 & 13,72 & 11,57 & 10,25 & & & \\
\hline Observations & 52,766 & 52,766 & 52,766 & 52,766 & & 52,766 & 52,766 \\
\hline Firms & 9,761 & 9,761 & 9,761 & 9,761 & & 9,761 & 9,761 \\
\hline Sample & importers & importers & importers & importers & & importers & importers \\
\hline Firm FE & YES & YES & YES & YES & & YES & YES \\
\hline Time FE & YES & YES & YES & YES & & YES & YES \\
\hline Cluster & Firm & Firm & Firm & Firm & & Firm & Firm \\
\hline
\end{tabular}

Table 7: Skill ratio of production and importing from labor-abundant countries (IV estimates).

The dependent variable in the second-stage regression (columns (5)-(6)) is the firm-level (log) skill ratio of production, defined as the ratio of non-production workers to production workers. The main explanatory variable of interest is the ratio of imports from set of labor-abundant countries relative to sales (import/sales below threshold). The specifications also include the ratio of imports from the set of skill-abundant countries relative to sales (imports/sales above threshold). We consider imports from countries with less than 95 percent of the French level of secondary schooling. Other controls are (all at the firm level and in logs): TFP (constructed with the Levinsohn-Petrin method), the number of employees, the capital-labor ratio and the value of exports. Both imports/sales below and above threshold are considered endogenous. Instruments are constructed from foreign supply-shocks (see data section for an explanation). First-stage regressions are reported in columns (1)-(4). We present Angrist-Pischke F-statistics for the joint significance of instruments with multiple endogenous variables. 


\begin{tabular}{|c|c|c|c|c|c|c|c|c|}
\hline \multicolumn{9}{|c|}{$\begin{array}{c}\text { dependent variable is } \log (\text { skill ratio })_{f, t} \\
\text { OLS Estimates }\end{array}$} \\
\hline & $(1)$ & $(2)$ & $(3)$ & $(4)$ & $(5)$ & $(6)$ & $(7)$ & $(8)$ \\
\hline skill intensity & $0.3791^{* * *}$ & $0.2572^{* * *}$ & 0.0340 & 0.0395 & $0.4184^{*}$ & $0.4078^{*}$ & $0.4156^{* *}$ & $0.4049^{* *}$ \\
\hline $\operatorname{imports}_{f, t}$ & $(0.069)$ & $(0.064)$ & $(0.029)$ & $(0.029)$ & $(0.185)$ & $(0.183)$ & $(0.185)$ & $(0.184)$ \\
\hline $\log (\mathrm{TFP})_{f, t}$ & & $\begin{array}{l}0.5478^{* * *} \\
(0.019)\end{array}$ & & $\begin{array}{r}-0.0058 \\
(0.012)\end{array}$ & & $\begin{array}{r}-0.0079 \\
(0.013)\end{array}$ & & $\begin{array}{r}-0.0078 \\
(0.013)\end{array}$ \\
\hline $\log (\text { employees })_{f, t}$ & & $\begin{array}{c}-0.1913^{* * *} \\
(0.010)\end{array}$ & & $\begin{array}{l}-0.2521^{* * *} \\
(0.024)\end{array}$ & & $\begin{array}{l}-0.2635^{* * *} \\
(0.026)\end{array}$ & & $\begin{array}{c}-0.2639^{* * *} \\
(0.026)\end{array}$ \\
\hline $\log (\text { capital/labor })_{f, t}$ & & $\begin{array}{l}-0.0590^{* * *} \\
(0.011)\end{array}$ & & $\begin{array}{l}-0.0603^{* * *} \\
(0.016)\end{array}$ & & $\begin{array}{l}-0.0602^{* * *} \\
(0.017)\end{array}$ & & $\begin{array}{l}-0.0602^{* * *} \\
\quad(0.017)\end{array}$ \\
\hline $\log$ (imports $)_{f, t}$ & & $\begin{array}{c}0.0622^{* * *} \\
(0.006)\end{array}$ & & $\begin{array}{c}0.0240 * * * \\
(0.006)\end{array}$ & & $\begin{array}{l}0.0294^{* * *} \\
(0.006)\end{array}$ & & $\begin{array}{c}0.0294^{* * *} \\
(0.006)\end{array}$ \\
\hline $\log (\text { exports })_{f, t}$ & & $\begin{array}{c}0.0331^{* * * *} \\
(0.004)\end{array}$ & & $\begin{array}{c}0.0059^{*} \\
(0.003)\end{array}$ & & $\begin{array}{l}0.0059 \\
(0.004)\end{array}$ & & $\begin{array}{l}0.0060 \\
(0.004)\end{array}$ \\
\hline Observations & 55,528 & 55,528 & 55,528 & 55,528 & 46,063 & 46,063 & 46,063 & 46,063 \\
\hline Firms & 13,343 & 13,343 & 13,343 & 13,343 & 8,856 & 8,856 & 8,856 & 8,856 \\
\hline Firm FE & NO & NO & YES & YES & YES & YES & YES & YES \\
\hline 4-digit sector FE & YES & YES & $\mathrm{NO}$ & $\mathrm{NO}$ & NO & NO & $\mathrm{NO}$ & $\mathrm{NO}$ \\
\hline Time FE & YES & YES & YES & YES & YES & YES & YES & YES \\
\hline Cluster & Firm & Firm & Firm & Firm & Firm & Firm & Firm & Firm \\
\hline R-squared & 0.2644 & 0.3405 & 0.0419 & 0.0570 & 0.0390 & 0.0556 & 0.0391 & 0.0558 \\
\hline \multicolumn{9}{|c|}{ First-stage regression: dependent variable is skill content of imports $_{f, t}$} \\
\hline tariff predicted skill intensity $_{f, t}$ & & & & & $\begin{array}{c}0.3806^{* * *} \\
(0.019)\end{array}$ & $\begin{array}{c}0.3802^{* * *} \\
(0.019)\end{array}$ & $\begin{array}{c}0.3827^{* * *} \\
(0.018)\end{array}$ & $\begin{array}{c}0.3823^{* * *} \\
(0.018)\end{array}$ \\
\hline supply-shock predicted skill intensity $f, t$ & & & & & & & $\begin{array}{l}-0,0016 \\
(0.0022)\end{array}$ & $\begin{array}{l}-0,0016 \\
(0.0022)\end{array}$ \\
\hline F-statistic & & & & & 420.43 & 418.98 & 212.86 & 212.13 \\
\hline Hansen $J$ statistic (p-value) & & & & & n.a. & n.a. & 0.95 & 0.81 \\
\hline
\end{tabular}

Table 8: Skill ratio of production and the skill intensity of imports from labor-abundant countries: OLS and IV estimates.

Columns (1)-(4) present OLS estimates and columns (5)-(6) present IV estimates. The main explanatory variable of interest is the average skill intensity of imports from labor-abundant countries. For an explanation of the construction of this variable see the data description. We consider imports from countries with less than 95 percent of the French level of secondary schooling (see the appendix for the results obtained using a 80 percent cutoff). Other controls are (all at the firm level and in logs): TFP (constructed with the Levinsohn-Petrin method), the number of employees, the capital-labor ratio, the value of imports and the value of exports. The skill content of imports is considered endogenous. The instruments are the tariff-predicted skill intensity of imports (columns 5 and 6) and the supply-shock predicted skill intensity of imports (columns (7) and (8)). See the data section for a discussion of the IV strategy. We report F-statistics for the joint significance of the instruments and the P-value for the Hansen over-identification test in $\left(H_{0}\right.$ : instruments uncorrelated with the residuals). 
We now turn to the results including firm fixed effects, which are reported in columns (3) and (4). Again, we find a positive partial correlation between the average skill intensity of imports and the (log) skill ratio. The estimates imply that a one-unit increase in firms' skill intensity of imports increases the skill ratio of production by around 3.46 percent but are not statistically significant. However, note that the fixed-effects estimates are again likely to be downward-biased since changes in the skill intensity of imports are subject to substantial measurement error. We will correct for this below by employing an IV strategy. Finally, observe that the estimates are unaffected by adding further controls and that TFP is no longer significant when including firm fixed effects. This is consistent with our theoretical model, which implies that productivity is a sufficient statistic for the skill intensity of imports, so an increase in productivity should not have any separate effect on the skill ratio of production besides the one that operates via the skill intensity of imports.

\section{Instrumental Variable Estimates}

Finally, we use the tariff-predicted skill intensity of imports as well as the supply-shock predicted skill intensity of imports from labor-abundant countries as instruments for the actual skill intensity of imports from these countries. The results of the two-stage-least-squares regressions with firm and time fixed effects are reported in columns (5)-(8) of Table 8. We first present regressions with the tariff-predicted skill intensity as the sole instrument in columns (5) and (6).

In the lower panel of the table, we present the first-stage coefficients for the regression of the skill intensity of imports on the tariff predicted skill intensity and the F-statistic for the excluded instrument. The first-stage coefficient for the tariff-predicted skill intensity of imports is around 0.38 and always significant at the one-percent level. Thus, the partial correlation of the instrument with the endogenous variable is positive and very strong. The F-statistics of the excluded instrument are extremely high, so weak instruments are not a concern.

Focusing now on the second-stage regressions (reported in the upper panel of the table), we find that the coefficient on the skill intensity of imports for the specifications with firm fixed effects is around 0.4, which is 10 times larger than the corresponding OLS estimates. Moreover, in contrast to the OLS estimates, the coefficients are all highly statistically significant. The fact that the IV estimates are larger than the OLS estimates is again plausibly due to an attenuation bias that stems from measurement error in the skill intensity of imports.

In columns (7) and(8) we use both instruments in the first stage and present over-identified 
results. Observe that the supply-shock instrument is not significant in the first stage, while the tariff instrument continues to be highly significant. Not surprisingly, the point estimates in the second stage are very similar to the specifications which use only the tariff instruments, since the regressions are effectively identified mostly through the tariff instrument. Finally, we cannot reject the null hypothesis of the over-identification test that the instruments are uncorrelated with the error term. Thus, the IV results confirm a causal positive effect of the skill intensity of imports from labor-abundant countries on the skill ratio of production in France.

\section{Conclusions}

In this paper we have developed a factor-proportions theory of offshoring with heterogeneous

firms. From the perspective of a skill-abundant country, high-productivity firms self-select into offshoring relatively labor-intensive inputs from labor-abundant countries, while producing skillintensive ones domestically. This leads to within-industry variation in skill intensity of production, with skill intensity correlating positively with productivity. A reduction in offshoring costs implies an increase in the skill-intensity of domestic production, as the marginal input that can be profitably offshored becomes more skill intensive. Moreover, our theory generates precise predictions on firm-level import patterns: first, more productive offshorers will source relatively more skillintensive inputs from labor-abundant countries than less productive ones; second, out of the set of labor-abundant countries, they will also source from relatively more skill-abundant locations. Using a quasi-exhaustive panel of French manufacturing firms we then show that the predicted patterns for the micro-economics of offshoring are strongly supported by the data. Finally, we use a foreign-supply shock based instrument and one based on the reduction in EU external tariffs in the late 90s to identify a causal impact of reduced offshoring costs on the increase in the skill intensity of French manufacturing firms. We find that the bulk of the observed within-firm increase in the skill intensity of importers from labor-abundant countries can be explained by increased imports from these countries.

This work is a first step in an attempt to understand how Heckscher-Ohlin forces operate at the within-industry and within-firm level. Our empirical analysis has provided some evidence that Heckscher-Ohlin driven offshoring can be a powerful driver for changes in the relative demand for skill within firms. An interesting avenue for future research is to develop a more structural version of our model in order to better understand its quantitative implications in general equilibrium. 


\section{References}

[1] Pol Antràs, 2003. "Firms, Contracts, And Trade Structure," Quarterly Journal of Economics, 118(4), 1375-1418.

[2] Pol Antràs, and Elhanan Helpman, 2004. "Global Sourcing," Journal of Political Economy, $112(3)$.

[3] Pol Antràs, Teresa Fort and Felix Tintelnot (2014). "The Margins of Global Sourcing: Theory and Evidence from U.S. Firms," manuscript.

[4] David Autor, David Dorn, and Gordon H. Hanson, 2013. "The China syndrome: local market effects of import competition in the U.S.," American Economic Review, 103(6), 2121-2168.

[5] Robert Barro and Jong-Wha Lee, 2013. "A new data set of educational attainment in the world, 1950-2010, " Journal of Development Economics, 104, 184-198.

[6] Eric J. Bartelsman and Wayne Gray, 1996. "The NBER Manufacturing Productivity Database," NBER Technical Working Paper 0205.

[7] Andrew B. Bernard, Stephen J. Redding and Peter K. Schott, 2007. "Comparative Advantage and Heterogeneous Firms," Review of Economic Studies, 74(1), 31-66.

[8] Pierre Biscourp, and Francis Kramarz, 2007. "Employment, skill structure and international trade: Firm-level evidence for France," Journal of International Economics, 72(1), 22-51.

[9] Pierre Cahuc, Fabien Postel-Vinay and Jean-Marc Robin, 2006. "Wage Bargaining with On-the-Job Search: Theory and Evidence," Econometrica, 74(2), 323-364.

[10] Lorenzo Caliendo, Ferdinando Monte and Esteban Rossi-Hansberg, 2015. "The Anatomy of French Production Hierarchies," Journal of Political Economy, forthcoming.

[11] Juan Carluccio, Denis Fougère and Erwan Gautier, 2015 "Trade, Wages, and Collective Bargaining: Evidence from France" Economic Journal, forthcoming.

[12] Gregory Corcos, Delphine Irac, Giordano Mion and Thierry Verdier, 2013. "The Determinants of Intra-Firm Trade, " Review of Economics and Statistics, 95(3), 835-838.

[13] Matthieu Crozet and Federico Trionfetti, 2013. "Firm-level Comparative Advantage, " Journal of International Economics, 91(2), 321-328.

[14] Jonathan Eaton and Samuel Kortum, 2002. "Technology, Geography, and Trade, "Econometrica, 70(5), 1741-1779.

[15] Robert C. Feenstra and Gordon H. Hanson, 1997. "Foreign direct investment and relative wages: Evidence from Mexico's maquiladoras," Journal of International Economics, 42(3-4), 371-393.

[16] Robert C. Feenstra and Gordon H. Hanson, 1999. "The Impact Of Outsourcing And HighTechnology Capital On Wages: Estimates For The United States, 1979-1990," Quarterly Journal of Economics, 114(3), 907-940.

[17] J. Michael Finger, Merlinda D. Ingco and Ulrich Reincke, 1996. "The Uruguay Round, Statistics on Tariff Concessions Given and Received " The World Bank.

[18] Gene M. Grossman and Esteban Rossi-Hansberg, 2008. "Trading Tasks: A Simple Theory of Offshoring," American Economic Review, 98(5), 1978-97.

[19] James Harrigan and Ariell Reshef, 2015. "Skill Biased Heterogeneous Firms, Trade Liberalization, and the Skill Premium," Canadian Journal of Economics, forthcoming.

[20] Elhanan Helpman, 1984. "A Simple Theory of International Trade with Multinational Corporations," Journal of Political Economy, 92(3), 451-471. 
[21] David Hummels, Rasmus Jørgensen, Jakob R. Munch and Chong Xiang, 2014. "The Wage Effects of Offshoring: Evidence from Danish Matched Worker-Firm Data," American Economic Review, 104(6), 1597-1629.

[22] James Levinsohn and Amil Petrin, 2003. "Estimating Production Functions Using Inputs to Control for Unobservables," Review of Economic Studies, 70(2), 317-341.

[23] Marc J. Melitz, 2003. "The Impact of Trade on Intra-Industry Reallocations and Aggregate Industry Productivity," Econometrica, 71(6), 1695-1725.

[24] Yue Ma, Heiwai Tang and Yifan Zhang, 2014. "Factor intensity, product switching, and productivity: Evidence from Chinese exporters," Journal of International Economics, 92, 349-362.

[25] Giordano Mion and Linke Zhu, 2013. "Import competition from and offshoring to China: A curse or blessing for firms?," Journal of International Economics, 89(1), 202-215.

[26] Justin R. Pierce and Peter K. Schott, 2009. "A Concordance Between Ten-Digit U.S. Harmonized System Codes and SIC/NAICS Product Classes and Industries, "NBER Working Papers 15548. 


\section{Appendix: For Online Publication}

\section{Appendix A: Proofs of the Two-Intermediate Model}

\section{A-1.1 Equilibrium Price Level and Mass of Firms}

Equations (9) and (10) enable us to express the price level $P$ and the mass of firms $M$ as functions of equilibrium outcomes $\gamma_{o}$ and $w_{l}$ :

$$
\begin{aligned}
P & =\frac{E}{\sigma M\left(f^{o} \gamma^{-a}+f^{e}\right)}, \\
M & =\left[\left(\frac{\sigma}{\sigma-1}\right)^{1-\sigma} \frac{2 a}{a-\sigma+1}\left[\frac{E}{\sigma\left(f^{o} \gamma^{-a}+f^{e}\right)}\right]^{\sigma-1}\left[w_{l}^{\frac{1-\sigma}{2}}\left(1-\gamma_{o}^{\sigma-a-1}\right)+\left(\tau^{o}\right)^{\frac{1-\sigma}{2}} \gamma_{o}^{\sigma-a-1}\right]\right]^{\frac{1}{\sigma-2}}(28)
\end{aligned}
$$

\section{A-1.2 Characterization of FMC}

\section{Slope}

Solving (12) for $\gamma_{o}^{\sigma-a-1}$ and differentiating with respect to $w_{l}$ yields

$$
\frac{\partial \gamma_{o}^{\sigma-a-1}}{\partial w_{l}}=\frac{\left[\frac{1}{4}(1-\sigma) w_{l}^{\frac{1-\sigma}{2}-1}\left(w_{l}^{-1} H / L-1\right)-\frac{1}{2} w_{l}^{\frac{1-\sigma}{2}-2} H / L\right]\left(\tau^{o}\right)^{\frac{1-\sigma}{2}}}{\left[\frac{1}{2} w_{l}^{\frac{1-\sigma}{2}}\left(w_{l}^{-1} H / L-1\right)+\left(\tau^{o}\right)^{\frac{1-\sigma}{2}}\right]^{2}}<0,
$$

since $w_{l}^{-1} H / L-1>0$ for $w_{l} \in(\tau, H / L)$. Since $\sigma-a-1<0, \partial \gamma_{o} / \partial w_{l}>0$.

$w_{l}=1$

Evaluating (12) at $w_{l}=1$ yields

$$
\gamma_{o}^{\sigma-a-1}=\frac{\frac{1}{2}(H / L-1)}{\frac{1}{2}(H / L-1)+\left(\tau^{o}\right)^{\frac{1-\sigma}{2}}} \in(0,1) .
$$

Since $\sigma-a-1<0, \gamma_{o}>1$.

$\gamma_{o} \rightarrow \infty$

Solving (12) for $\gamma_{o}^{\sigma-a-1}$, we have that when we let $\gamma_{0} \rightarrow \infty$, the LHS of the resulting expression tends to 0 . Thus, for the RHS to match the LHS, $w_{l} \rightarrow H / L$.

\section{Shifts of the FMC Schedule}

Relative factor endowments Differentiating $\gamma_{o}^{\sigma-a-1}$ with respect to $H / L$,

$$
\frac{\partial \gamma_{o}^{\sigma-a-1}}{\partial(H / L)}=\frac{\frac{1}{2} w_{l}^{\frac{1-\sigma}{2}-1}}{\left[\frac{1}{2} w_{l}^{\frac{1-\sigma}{2}}\left(w_{l}^{-1} H / L-1\right)+\left(\tau^{o}\right)^{\frac{1-\sigma}{2}}\right]^{2}}>0 .
$$

Hence, $\partial \gamma_{o} / \partial(H / L)<0$. 
Variable cost of offshoring Differentiating $\gamma_{o}^{\sigma-a-1}$ with respect to $\tau^{o}$,

$$
\frac{\partial \gamma_{o}^{\sigma-a-1}}{\partial \tau^{o}}=-\frac{\frac{1}{4}(1-\sigma) w_{l}^{\frac{1-\sigma}{2}}\left(w_{l}^{-1} H / L-1\right)\left(\tau^{o}\right)^{\frac{1-\sigma}{2}-1}}{\left[\frac{1}{2} w_{l}^{\frac{1-\sigma}{2}}\left(w_{l}^{-1} H / L-1\right)+\left(\tau^{o}\right)^{\frac{1-\sigma}{2}}\right]^{2}}>0 .
$$

Hence, $\partial \gamma_{o} / \partial \tau^{o}<0$.

\section{A-1.3 Characterization of OFE}

\section{Slope}

Differentiating $\Phi_{O F E}$ with respect to $\gamma_{o}$,

$$
\begin{aligned}
& \frac{\partial \Phi_{O F E}}{\partial \gamma_{o}}=\frac{a-\sigma+1}{a}\left[\left(\tau^{o}\right)^{\frac{1-\sigma}{2}}-w_{l}^{\frac{1-\sigma}{2}}\right]\left[w_{l}^{\frac{1-\sigma}{2}}\left(1-\gamma_{o}^{\sigma-a-1}\right)+\left(\tau^{o}\right)^{\frac{1-\sigma}{2}} \gamma_{o}^{\sigma-a-1}\right]^{-2} . \\
& \cdot\left[\left[(\sigma-1) \gamma_{o}^{\sigma-2}\left(\gamma_{o}^{-a}+f^{e} / f^{o}\right)-a \gamma_{o}^{\sigma-a-2}\right]\left[w_{l}^{\frac{1-\sigma}{2}}\left(1-\gamma_{o}^{\sigma-a-1}\right)+\left(\tau^{o}\right)^{\frac{1-\sigma}{2}} \gamma_{o}^{\sigma-a-1}\right]+\right. \\
& \left.-\gamma_{o}^{\sigma-1}\left(\gamma_{o}^{-a}+f^{e} / f^{o}\right)(\sigma-a-1) \gamma_{o}^{\sigma-a-2}\left[1-w_{l}^{\frac{1-\sigma}{2}}\right]\right] .
\end{aligned}
$$

All terms are unambiguosly positive except for

$$
\left[(\sigma-1) \gamma_{o}^{\sigma-2}\left(\gamma_{o}^{-a}+f^{e} / f^{o}\right)-a \gamma_{o}^{\sigma-a-2}\right] .
$$

Assuming this term is positive,

$$
\left[(\sigma-1) \gamma_{o}^{\sigma-2}\left(\gamma_{o}^{-a}+f^{e} / f^{o}\right)-a \gamma_{o}^{\sigma-a-2}\right]>0 \Leftrightarrow \gamma_{o}>\left[\frac{a-\sigma+1}{\sigma-1} \frac{f^{o}}{f^{e}}\right]^{1 / a} .
$$

Thus, $\left[(a-\sigma+1) f^{o}\right] /\left[(\sigma-1) f^{e}\right]<1$ is a sufficient condition for $\partial \Phi_{O F E} / \partial \gamma_{o}>0$.

Differentiating $\Phi_{O F E}$ with respect to $w_{l}$

$$
\begin{aligned}
& \frac{\partial \Phi_{O F E}}{\partial w_{l}}=\frac{(\sigma-1)(a-\sigma+1)}{a\left(\gamma_{o}^{-a}+f^{e} / f^{o}\right)^{-1}} \gamma_{o}^{\sigma-1}\left[w_{l}^{\frac{1-\sigma}{2}}\left(1-\gamma_{o}^{\sigma-a-1}\right)+\left(\tau^{o}\right)^{\frac{1-\sigma}{2}} \gamma_{o}^{\sigma-a-1}\right]^{-2} \frac{1}{2} w_{l}^{\frac{1-\sigma}{2}-1} . \\
& \cdot\left[\left[w_{l}^{\frac{1-\sigma}{2}}\left(1-\gamma_{o}^{\sigma-a-1}\right)+\left(\tau^{o}\right)^{\frac{1-\sigma}{2}} \gamma_{o}^{\sigma-a-1}\right]+\left(1-\gamma_{o}^{\sigma-a-1}\right)\left[\left(\tau^{o}\right)^{\frac{1-\sigma}{2}}-w_{l}^{\frac{1-\sigma}{2}}\right]\right]>0 .
\end{aligned}
$$

Thus, under the condition $\left[(a-\sigma+1) f^{o}\right] /\left[(\sigma-1) f^{e}\right]<1$,

$$
\frac{\partial \gamma_{o}}{\partial w_{l}}=-\frac{\partial \Phi_{O F E} / \partial w_{l}}{\partial \Phi_{O F E} / \partial \gamma_{o}}<0
$$

$w_{l} \rightarrow 1$

Equation (13) can be written as

$$
\frac{\frac{a-\sigma+1}{a}\left[\left(\tau^{o}\right)^{\frac{1-\sigma}{2}}-w_{l}^{\frac{1-\sigma}{2}}\right]}{\left[w_{l}^{\frac{1-\sigma}{2}}\left(1-\gamma_{o}^{\sigma-a-1}\right)+\left(\tau^{o}\right)^{\frac{1-\sigma}{2}} \gamma_{o}^{\sigma-a-1}\right]}=\frac{\gamma_{o}^{1-\sigma}}{\left(\gamma_{o}^{-a}+f^{e} / f^{o}\right)} .
$$


As $w_{l} \rightarrow \tau$, the LHS tends to zero. For the RHS to match this, we need that $\gamma_{o} \rightarrow \infty$.

\section{Shifts of the OFE Schedule}

Fixed costs Differentiating $\Phi_{O F E}$ with respect to $f^{e} / f^{o}$,

$$
\frac{\partial \Phi_{O F E}}{\partial\left(f^{e} / f^{o}\right)}=\frac{\frac{a-\sigma+1}{a} \gamma_{o}^{\sigma-1}\left[\left(\tau^{o}\right)^{\frac{1-\sigma}{2}}-w_{l}^{\frac{1-\sigma}{2}}\right]}{w_{l}^{\frac{1-\sigma}{2}}\left(1-\gamma_{o}^{\sigma-a-1}\right)+\left(\tau^{o}\right)^{\frac{1-\sigma}{2}} \gamma_{o}^{\sigma-a-1}}>0 .
$$

Thus, under the condition $\left[(a-\sigma+1) f^{o}\right] /\left[(\sigma-1) f^{e}\right]<1$,

$$
\frac{\partial \gamma_{o}}{\partial\left(f^{e} / f^{o}\right)}=-\frac{\partial \Phi_{O F E} / \partial\left(f^{e} / f^{o}\right)}{\partial \Phi_{O F E} / \partial \gamma_{o}}<0
$$

Hence, $\partial \gamma_{o} / \partial f^{e}<0$ and $\partial \gamma_{o} / \partial f^{o}>0$.

Variable cost of offshoring Differentiating $\Phi_{O F E}$ with respect to $\tau^{o}$,

$$
\frac{\partial \Phi_{O F E}}{\partial \tau^{o}}=\frac{\frac{a-\sigma+1}{a} \gamma_{o}^{\sigma-1}\left(\gamma_{o}^{-a}+f^{e} / f^{o}\right) \frac{1}{2}(1-\sigma)\left(\tau^{o}\right)^{\frac{1-\sigma}{2}-1} w_{l}^{\frac{1-\sigma}{2}}}{\left[w_{l}^{\frac{1-\sigma}{2}}\left(1-\gamma_{o}^{\sigma-a-1}\right)+\left(\tau^{o}\right)^{\frac{1-\sigma}{2}} \gamma_{o}^{\sigma-a-1}\right]^{2}}<0
$$

Thus, under the condition $\left[(a-\sigma+1) f^{o}\right] /\left[(\sigma-1) f^{e}\right]<1$,

$$
\frac{\partial \gamma_{o}}{\partial \tau^{o}}=-\frac{\partial \Phi_{O F E} / \partial \tau^{o}}{\partial \Phi_{O F E} / \partial \gamma_{o}}>0
$$

Comparative statics of $\tau^{o}$

Applying the implicit function theorem to the system of equations (12)-(13) yields

$$
\frac{\partial \gamma_{o}}{\partial \tau^{o}}=-\frac{\frac{\partial \Phi_{O F E}}{\partial w_{l}} \frac{\partial \Phi_{F M C}}{\partial \tau^{o}}-\frac{\partial \Phi_{F M C}}{\partial w_{l}} \frac{\partial \Phi_{O F E}}{\partial \tau^{\circ}}}{\frac{\partial \Phi_{F M C}}{\partial \tau^{o}} \frac{\partial \Phi_{O F E}}{\partial w_{l}}-\frac{\partial \Phi_{F M C}}{\partial w_{l}} \frac{\partial \Phi_{O F E}}{\partial \gamma_{o}}} .
$$

It is easy to see that the denominator is positive: $\partial \Phi_{F M C} / \partial \tau^{o}>0, \partial \Phi_{O F E} / \partial w_{l}>0, \partial \Phi_{F M C} / \partial w_{l}<$ 0 and $\partial \Phi_{O F E} / \partial \gamma_{o}>0$. As for the numerator,

$$
\operatorname{sign}\left\{\frac{\partial \Phi_{O F E}}{\partial w_{l}} \frac{\partial \Phi_{F M C}}{\partial \tau^{o}}-\frac{\partial \Phi_{F M C}}{\partial w_{l}} \frac{\partial \Phi_{O F E}}{\partial \tau^{o}}\right\}=\operatorname{sign}\left\{-\frac{1}{2} w_{l}^{\frac{1-\sigma}{2}-2}\left(\tau^{o}\right)^{\frac{1-\sigma}{2}} H / L\right\}<0 .
$$

Thus, $\partial \gamma_{o} / \partial \tau^{o}>0$.

\section{Appendix B: A Many-country Model with a Continuum of Intermediate Inputs}

A-2.4 Cutoff inputs $z_{12}$ and $z_{23}$

The cutoff inputs ilustrated in Figure 7 are defined by

$$
\begin{aligned}
\tau^{o} w_{h 1}^{z_{12}} w_{l 1}^{1-z_{12}} & =\tau^{o} w_{h 2}^{z_{12}} w_{l 2}^{1-z_{12}} \\
\tau^{o} w_{h 2}^{z_{23}} w_{l 2}^{1-z_{23}} & =w_{h 3}^{z_{23}} w_{l 3}^{1-z_{23}} .
\end{aligned}
$$


Given factor prices, it is easy to see that $\ln \tau^{o}+z \log \left(w_{h 1}\right)+(1-z) \log \left(w_{l 1}\right)$ is increasing in $z$, $\ln \tau^{o}+z \log \left(w_{h 2}\right)+(1-z) \log \left(w_{l 2}\right)=\ln \tau^{o}$ for all $z$, and $z \log \left(w_{h 3}\right)+(1-z) \log \left(w_{l 3}\right)$ is decreasing in $z$.

\section{A-2.5 Marginal costs}

A country-3 firm may offshore no inputs $\left(z_{3}^{o}=0\right)$, offshore from country 1 only $\left(z_{3}^{o} \in\left[0, z_{12}\right]\right)$, or offshore from country 1 and country $2\left(z_{3}^{o} \in\left[z_{12}, z_{23}\right]\right)$. It is easy to show that a country-3 firm would not offshore to country 2 only.

For $z_{3}^{o}=0$, the marginal cost of country-3 firm is

$$
M C_{0}(\gamma)=\frac{1}{\gamma} \int_{0}^{1} \ln \left(w_{h 3}^{z} w_{l 3}^{1-z}\right) d z=\frac{1}{\gamma} w_{h 3}^{1 / 2} w_{l 3}^{1 / 2}
$$

For $z_{3}^{o} \in\left(0, z_{12}\right]$,

$$
M C_{1}(\gamma)=\frac{1}{\gamma}\left[\int_{0}^{z_{3}^{o}} \ln \left(\tau^{o} w_{h 1}^{z} w_{l 1}^{1-z}\right) d z+\int_{z_{3}^{o}}^{1} \ln \left(w_{h 3}^{z} w_{l 3}^{1-z}\right) d z\right]=\frac{\left(\tau^{o}\right)^{z_{3}^{o}}}{\gamma} w_{h 3}^{1 / 2+z_{3}^{o}-\left(z_{3}^{o}\right)^{2}} w_{l 3}^{1 / 2-z_{3}^{o}+\left(z_{3}^{o}\right)^{2}} .
$$

For $z_{3}^{o} \in\left(z_{12}, z_{23}\right]$,

$$
\begin{aligned}
M C_{2}(\gamma) & =\frac{1}{\gamma}\left[\int_{0}^{z_{12}} \ln \left(\tau^{o} w_{h 1}^{z} w_{l 1}^{1-z}\right) d z+\int_{z_{12}}^{z_{3}^{o}} \ln \left(\tau^{o} w_{h 2}^{z} w_{l 2}^{1-z}\right) d z+\int_{z_{3}^{o}}^{1} \ln \left(w_{h 3}^{z} w_{l 3}^{1-z}\right) d z\right] \\
& =\frac{\left(\tau^{o}\right)^{z_{3}^{o}}}{\gamma} w_{h 3}^{1 / 2-1 / 2\left[z_{3}^{o}\right]^{2}+z_{12}-1 / 2\left[z_{12}\right]^{2}} w_{l 3}^{1 / 2-z_{3}^{o}+1 / 2\left[z_{3}^{o}\right]^{2}+1 / 2\left[z_{12}\right]^{2}} .
\end{aligned}
$$

The following results are easy to show:

1. For $z_{3}^{o} \in\left(0, z_{12}\right], \partial M C_{1} / \partial z_{3}^{o}=M C_{1}\left[\ln \tau^{o}+\left(2 z_{3}^{o}-1\right) \log \left(w_{l 3} / w_{h 3}\right)\right]=M C_{1} B_{1}$. From Figure $7, B_{1}<0$.

2. For $z_{3}^{o} \in\left(z_{12}, z_{23}\right], \partial M C_{2} / \partial z_{3}^{o}=M C_{2}\left[\ln \tau^{o}\left[\left[z_{3}^{o}-1\right] \log w_{l 3}-z_{3}^{o} \log \left(w_{h 3}\right)\right]\right]=M C_{2} B_{2}$. Again from Figure $7, B_{2}<0$.

3. The marginal cost function is continuous at $z_{12}$ : evaluating equations (48) and (49) at $z_{12}$ yields the same value.

4. The marginal cost function is differentiable at $z_{12}$ : evaluating $\partial M C_{1} / \partial z_{3}^{o}$ and $\partial M C_{2} / \partial z_{3}^{o}$ at $z_{12}$ yields the same value.

5. For $z_{3}^{o} \in\left(0, z_{12}\right]$ and for $z_{3}^{o} \in\left(z_{12}, z_{23}\right], \partial^{2} M C_{1} / \partial\left(z_{3}^{o}\right)^{2}=M C\left(B^{2}+\partial B / \partial z_{3}^{o}\right)>0$

6. We cannot rule out the possibility of a kink in $\partial M C / \partial z_{3}^{o}$ at $z_{3}^{o}=z_{12}$. However, the function $M C$ is still convex in $z_{3}^{o}$ due to results 1-5.

\section{A-2.6 Variable profits}

Conditional upon entry, firms in country 3 maximize

$$
\max _{p, z_{3}^{o}} \Pi(z)=\max _{p, z_{3}^{o}} p(\gamma) q(\gamma)-M C(\gamma) q(\gamma)-z_{3}^{o} P f^{o},
$$


The first order condition with respect to $p$ yields

$$
p=\frac{\sigma}{\sigma-1} M C
$$

We define variable profits as

$$
\begin{aligned}
\pi\left(\gamma, z_{3}^{o}\right) & =\left[p\left(\gamma, z_{3}^{o}\right)-M C\left(\gamma, z_{3}^{o}\right)\right] q\left(\gamma, z_{3}^{o}\right)= \\
& =\frac{1}{\sigma}\left(\frac{\sigma}{\sigma-1}\right) M C\left(z_{3}^{o}\right)^{1-\sigma} P^{\sigma-1} \sum_{j}\left(w_{h j} H_{j}+w_{l j} L_{j}\right)
\end{aligned}
$$

Since variable profits are an inverse function of marginal costs,

$$
\frac{\partial \pi\left(\gamma, z_{3}^{o}\right)}{\partial z_{3}^{o}} \propto M C^{1-\sigma} B>0
$$

$\partial^{2} \pi\left(\gamma, z_{3}^{o}\right) / \partial\left(z_{3}^{o}\right)^{2}<0$, and $\partial^{2} \pi\left(\gamma, z_{3}^{o}\right) / \partial z_{3}^{o} \partial \gamma>0$. There is the possibility of a kink in $\partial \pi / \partial z_{3}^{o}$ at $z_{3}^{o}=z_{12}$, but $\pi$ is still concave in $z_{3}^{o}$. Finally,

$$
\frac{\partial^{2} \pi\left(\gamma, z_{3}^{o}\right)}{\partial z_{3}^{o} \partial \tau^{o}} \propto(1-\sigma)\left[(1-\sigma) M C^{-\sigma} \frac{\partial M C}{\partial \tau} B+M C^{1-\sigma} \frac{\partial B}{\partial \tau^{o}}\right]<0 .
$$




\section{Appendix C: Additional Figures and Tables}

\begin{tabular}{lccccc}
\hline \hline Variable & Mean & Std. Dev. & 5th Pct. & 95th Pct. & Obs. \\
\hline Skill ratio & & & & & \\
Employees & 1.18 & 4.50 & 0.14 & 3.50 & 646,920 \\
(log) TFP & 53.51 & 336.58 & 3.00 & 174.00 & 646,920 \\
(log) Capital/labor & 33.48 & 18.07 & 2.67 & 63.70 & 646,920 \\
Imports (in 1000 euros) & 40.49 & 43.14 & 1.52 & 125.80 & 646,920 \\
Exports (in 1000 euros) & 1.375 & 26.606 & 0 & 3.030 & 646,920 \\
Number of products imported (all sources) & 1.908 & 24.403 & 0 & 4.047 & 646,920 \\
Number of products imported (95\% cutoff) & 6.080 & 16.719 & 0 & 29,00 & 64,920 \\
Number of origin countries (all sources) & 1.863 & 3.959 & 1 & 24,00 & 96,982 \\
Number of origin countries (95 \% cutoff) & 2.729 & 3.079 & 1 & 10,00 & 646,920 \\
\hline \hline
\end{tabular}

Table A-1: Summary Statistics Summary statistics for the baseline estimating sample. $95 \%$ cutoff refers to the group of countries with a level secondary schooling less than $95 \%$ of that of France. See Table A2 for the list of countries. 
Table A-2: Country List

\begin{tabular}{|c|c|}
\hline \multicolumn{2}{|c|}{$\begin{array}{l}\text { Secondary schooling relative to France } \\
\text { countries with less than } 95 \text { percent }\end{array}$} \\
\hline Afghanistan & Liberia \\
\hline Albania & Libya \\
\hline Algeria & Macao \\
\hline Argentina & Malawi \\
\hline Bahrain & Malaysia \\
\hline Bangladesh & Maldives \\
\hline Barbados & Mali \\
\hline Belize & Malta \\
\hline Benin & Mauritania \\
\hline Bolivia & Mauritius \\
\hline Botswana & Mexico \\
\hline Brazil & Morocco \\
\hline Bulgaria & Mozambique \\
\hline Burundi & Namibia \\
\hline Cambodia & Nepal \\
\hline Cameroon & New Zealand \\
\hline Central African R. & Nicaragua \\
\hline Chile & Niger \\
\hline China & Pakistan \\
\hline Colombia & Panama \\
\hline Congo, Republic of & Papua New Guinea \\
\hline Costa Rica & Paraguay \\
\hline Cote d'Ivoire & Peru \\
\hline Croatia & Philippines \\
\hline Cuba & Poland \\
\hline Cyprus & Qatar \\
\hline Czech Republic & Romania \\
\hline Dominican Republic & Rwanda \\
\hline Ecuador & Saudi Arabia \\
\hline Egypt & Senegal \\
\hline El Salvador & Sierra Leone \\
\hline Fiji & Singapore \\
\hline Gabon & Slovak Republic \\
\hline Gambia & Slovenia \\
\hline Ghana & South Africa \\
\hline Greece & Sri Lanka \\
\hline Guatemala & Sudan \\
\hline Guyana & Swaziland \\
\hline Haiti & Syria \\
\hline Honduras & Taiwan \\
\hline Hong Kong & Tanzania \\
\hline Hungary & Thailand \\
\hline India & $\begin{array}{l}\text { Togo } \\
\text { Toge }\end{array}$ \\
\hline Indonesia & Tonga \\
\hline Iran & Trinidad \\
\hline Iraq & Tunisia \\
\hline Jamaica & Turkey \\
\hline Japan & Uganda \\
\hline Jordan & United Arab Emirates \\
\hline Kenya & Uruguay \\
\hline Kuwait & Venezuela \\
\hline Laos & Vietnam \\
\hline Latvia & Yemen \\
\hline Lesotho & Zambia \\
\hline & Zimbabwe \\
\hline
\end{tabular}




\begin{tabular}{|c|c|c|c|c|}
\hline \multicolumn{5}{|c|}{$\begin{array}{l}\text { Dependent variable is skill intensity of imports } f t \\
\text { from countries } \leq 80 \text { percent of French sec. schooling }\end{array}$} \\
\hline & $(1)$ & $(3)$ & $(2)$ & (4) \\
\hline $\log (\mathbf{T F P})_{f, t-1}$ & $\begin{array}{c}\mathbf{0 . 0 0 5 8 * * *} \\
(0.001)\end{array}$ & $\begin{array}{c}\mathbf{0 . 0 0 2 9}^{*} \\
(0.002)\end{array}$ & $\begin{array}{c}\mathbf{0 . 0 0 3 9}^{* *} \\
(0.002)\end{array}$ & $\begin{array}{c}\mathbf{0 . 0 0 3 1}^{*} \\
(0.002)\end{array}$ \\
\hline $\log (\text { employees })_{f, t}$ & & $\begin{array}{c}-0.0028^{* * *} \\
(0.001)\end{array}$ & & $\begin{array}{l}0.0012 \\
(0.002)\end{array}$ \\
\hline \multirow[t]{2}{*}{$\log (\text { capital/labor })_{f, t}$} & & $0.0023^{* * *}$ & & \\
\hline & & $(0.001)$ & & $(0.002)$ \\
\hline \multirow[t]{2}{*}{$\log (\text { exports })_{f, t}$} & & -0.0003 & & 0.0007 \\
\hline & & $(0.000)$ & & $(0.001)$ \\
\hline \multirow[t]{2}{*}{$\log (\text { imports })_{f, t}$} & & $0.0035^{* * *}$ & & $0.0019^{* *}$ \\
\hline & & $(0.001)$ & & $(0.001)$ \\
\hline Observations & 48,340 & 48,340 & 48,340 & 48,340 \\
\hline Firms & 12,047 & 12,047 & 12,047 & 12,047 \\
\hline Firm FE & NO & NO & YES & YES \\
\hline 4-digit Sector FE & YES & YES & NO & NO \\
\hline Time FE & YES & YES & YES & YES \\
\hline Cluster & Firm & Firm & Firm & Firm \\
\hline R-squared & 0.3258 & 0.3279 & 0.0057 & 0.0061 \\
\hline
\end{tabular}

Table A-3: Skill-intensity of imports from labor-abundant countries and productivity

The dependent variable is the average skill intensity of imports from labor-abundant countries at the firm level (see the data section for an explanation of the construction of this variable). We consider imports from countries with less than 80 percent of the French level of secondary schooling. The main explanatory variable of interest is the one-year lag of firm-level productivity computed with the Levinsohn-Petrin method, $\log (T F P)_{f, t}$. Other controls are (all at the firm level and in logs): the number of employees, the capital-labor ratio and the value of exports and imports. 


\begin{tabular}{|c|c|c|c|c|c|c|c|c|}
\hline \multicolumn{9}{|c|}{ dependent variable is $\log$ (skill ratio) $f t$; countries $\leq 95$ percent of French sec. schooling } \\
\hline & $(1)$ & $(2)$ & $(3)$ & $(4)$ & $(5)$ & $(6)$ & $(7)$ & $(8)$ \\
\hline import status & $0.1980 * * *$ & $0.2517 * * *$ & $0.0429 * * *$ & $0.0474 * * *$ & & & & \\
\hline below threshold $_{f, t}$ & $(0.010)$ & $(0.009)$ & $(0.004)$ & $(0.004)$ & & & & \\
\hline imports/sales & & & & & $0.2659^{* *}$ & $0.2487^{* *}$ & $0.2325 * *$ & $0.1853^{*}$ \\
\hline $\begin{array}{l}\text { below threshold } \\
\text { import status } \\
\text { im }\end{array}$ & $-0.0260 * * *$ & 0.0032 & $-0.0121 * * *$ & 0.0029 & & & & \\
\hline above threshold $f, t$ & $(0.006)$ & $(0.006)$ & $(0.003)$ & $(0.003)$ & & & & \\
\hline $\begin{array}{l}\text { imports/sales } \\
\text { above threshold } f, t\end{array}$ & & & & & $\begin{array}{r}-0.0086 \\
(0.006)\end{array}$ & $\begin{array}{r}-0.0082 \\
(0.006)\end{array}$ & $\begin{array}{l}-0.0245 \\
(0.016)\end{array}$ & $\begin{array}{c}-0.0368^{* *} \\
(0.016)\end{array}$ \\
\hline $\log (\mathrm{TFP})_{f, t}$ & & $\begin{array}{c}0.3925^{* * *} \\
(0.006)\end{array}$ & & $\begin{array}{c}-0.0112^{* * *} \\
(0.004)\end{array}$ & & $\begin{array}{c}-0.0124^{* * *} \\
(0.004)\end{array}$ & & $\begin{array}{r}-0.0011 \\
(0.012)\end{array}$ \\
\hline $\log (\text { employees })_{f, t}$ & & $\begin{array}{c}-0.1801^{* * *} \\
(0.003)\end{array}$ & & $\begin{array}{c}-0.1708^{* * *} \\
(0.005)\end{array}$ & & $\begin{array}{c}-0.1721^{* * *} \\
(0.005)\end{array}$ & & $\begin{array}{c}-0.2407^{* * *} \\
(0.026)\end{array}$ \\
\hline $\log (\text { capital/labor })_{f, t}$ & & $\begin{array}{c}0.0237^{* * *} \\
(0.003)\end{array}$ & & $\begin{array}{c}-0.0183^{* * *} \\
(0.004)\end{array}$ & & $\begin{array}{c}-0.0186^{* * *} \\
(0.004)\end{array}$ & & $\begin{array}{c}-0.0463^{* * *} \\
(0.017)\end{array}$ \\
\hline $\operatorname{export}_{\text {status }} f, t$ & & $\begin{array}{c}0.1410^{* * *} \\
(0.006)\end{array}$ & & $\begin{array}{c}0.0156^{* * *} \\
(0.003)\end{array}$ & & & & \\
\hline $\log (\text { exports })_{f, t}$ & & & & & & $\begin{array}{c}0.0077^{* * *} \\
(0.001)\end{array}$ & & $\begin{array}{c}0.0106^{* * *} \\
(0.004)\end{array}$ \\
\hline Observations & 646,920 & 646,920 & 646,920 & 646,920 & 646,920 & 646,920 & 49,613 & 49,613 \\
\hline Firms & 104,036 & 104,037 & 104,038 & 104,039 & 104,036 & 104,036 & 11,763 & 11,763 \\
\hline Sample & all & all & all & all & all & all & importers & importers \\
\hline Firm FE & $\mathrm{NO}$ & NO & YES & YES & YES & YES & YES & YES \\
\hline 4-digit sector FE & YES & YES & $\mathrm{NO}$ & $\mathrm{NO}$ & NO & $\mathrm{NO}$ & NO & NO \\
\hline Time FE & YES & YES & YES & YES & YES & YES & YES & YES \\
\hline Cluster & Firm & Firm & Firm & Firm & Firm & Firm & Firm & Firm \\
\hline R-squared & 0.2037 & 0.2508 & 0.0040 & 0.0112 & 0.0042 & 0.0114 & 0.0509 & 0.0660 \\
\hline
\end{tabular}

Table A-4: Skill ratio of production and importing from labor-abundant countries (extensive and intensive margin).

The dependent variable is the firm-level $(\log )$ skill ratio of production, defined as the ratio of non-production workers to production workers. We consider imports from countries with less than 80 percent of the French level of secondary schooling. In columns (1)-(4), the main explanatory variable of interest is a dummy for importing from the set of labor-abundant countries (import status below threshold). The specifications also include a dummy for importing from the set of skillabundant countries (import status above threshold). In columns (5)-(8), the main explanatory variable of interest is the ratio of imports from set of labor-abundant countries relative to sales (import/sales below threshold). The specifications also include the ratio of imports from the set of skill-abundant countries relative to sales (imports/sales above threshold). Other controls are (all at the firm level and in logs): TFP (constructed with the Levinsohn-Petrin method), the number of employees, the capital-labor ratio and the value of exports. 


\begin{tabular}{|c|c|c|c|c|c|c|c|}
\hline \multirow[t]{2}{*}{ First Stage } & \multicolumn{2}{|c|}{$\begin{array}{l}\text { Dep. var.: imports/sales } \\
\text { below threshold } f, t\end{array}$} & \multicolumn{2}{|c|}{$\begin{array}{l}\text { Dep. var.: imports/sales } \\
\text { above threshold } f, t\end{array}$} & \multirow[t]{2}{*}{ Second Stage } & \multicolumn{2}{|c|}{ Dep. var.: $\log (\text { skill ratio })_{f, t}$} \\
\hline & $(1)$ & $(2)$ & $(3)$ & $(4)$ & & $(5)$ & $(6)$ \\
\hline IV Supply Shock (below) & $\begin{array}{c}0.0023^{* * *} \\
(0.0007)\end{array}$ & $\begin{array}{c}0.0021^{* * *} \\
(0.0007)\end{array}$ & $\begin{array}{l}0.0022^{*} \\
(0.0013)\end{array}$ & $\begin{array}{c}0.0021 \\
(0.0013)\end{array}$ & imports/sales (below) & $\begin{array}{c}4.7407^{* *} \\
(2.282)\end{array}$ & $\begin{array}{c}4.4903^{* *} \\
(2.220)\end{array}$ \\
\hline IV Supply Shock (above) & $\begin{array}{c}-0.0070^{* *} \\
(0.0034)\end{array}$ & $\begin{array}{c}-0.0066^{*} \\
(0.0034)\end{array}$ & $\begin{array}{c}0.0090^{* * *} \\
(0.0034)\end{array}$ & $\begin{array}{c}0.0091^{* *} \\
(0.0031)\end{array}$ & imports/sales (above) & $\begin{array}{c}-3.5204^{*} \\
(1.987)\end{array}$ & $\begin{array}{r}-2.8695 \\
(1.914)\end{array}$ \\
\hline $\log (\mathrm{TFP})_{f, t}$ & & $\begin{array}{c}-0.0046^{* *} \\
(0.0020)\end{array}$ & & $\begin{array}{c}-0.0155^{* * *} \\
(0.0033)\end{array}$ & $\log (\mathrm{TFP})_{f, t}$ & & $\begin{array}{r}-0.0238 \\
(0.035)\end{array}$ \\
\hline $\log (\text { employees })_{f, t}$ & & $\begin{array}{c}-0.0287^{* * *} \\
(0.0034)\end{array}$ & & $\begin{array}{c}-0.0200^{* * *} \\
(0.0067)\end{array}$ & $\log (\text { employees })_{f, t}$ & & $\begin{array}{c}-0.1710^{* *} \\
(0.081)\end{array}$ \\
\hline $\log (\text { capital/labor })_{f, t}$ & & $\begin{array}{l}-0.0028 \\
(0.0024)\end{array}$ & & $\begin{array}{l}-0.0007 \\
(0.0033)\end{array}$ & $\log (\text { capital/labor })_{f, t}$ & & $\begin{array}{r}-0.0350 \\
(0.022)\end{array}$ \\
\hline $\log (\text { exports })_{f, t}$ & & $\begin{array}{c}0.0087^{* * *} \\
(0.0007)\end{array}$ & & $\begin{array}{c}0.0107^{* * *} \\
(0.0009)\end{array}$ & $\log (\text { exports })_{f, t}$ & & $\begin{array}{l}0.0037 \\
(0.031)\end{array}$ \\
\hline F-statistic (Angrist-Pischke) & 17,01 & 12,47 & 15,81 & 11,51 & & & \\
\hline Observations & 46,780 & 46,780 & 46,780 & 46,780 & & 46,780 & 46,780 \\
\hline Firms & 8,930 & 8,930 & 8,930 & 8,930 & & 8,930 & 8,930 \\
\hline Sample & importers & importers & importers & importers & & importers & importers \\
\hline Firm FE & YES & YES & YES & YES & & YES & YES \\
\hline Time FE & YES & YES & YES & YES & & YES & YES \\
\hline Cluster & Firm & Firm & Firm & Firm & & Firm & Firm \\
\hline
\end{tabular}

Table A-5: Skill ratio of production and importing from labor-abundant countries (IV estimates).

The dependent variable in the second-stage regression (columns (5)-(6)) is the firm-level (log) skill ratio of production, defined as the ratio of non-production workers to production workers. The main explanatory variable of interest is the ratio of imports from set of labor-abundant countries relative to sales (import/sales below threshold). The specifications also include the ratio of imports from the set of skill-abundant countries relative to sales (imports/sales above threshold). We consider imports from countries with less than 80 percent of the French level of secondary schooling. Other controls are (all at the firm level and in logs): TFP (constructed with the Levinsohn-Petrin method), the number of employees, the capital-labor ratio and the value of exports. Both imports/sales below and above threshold are considered endogenous. Instruments are constructed from foreign supply-shocks (see data section for an explanation). First-stage regressions are reported in columns (1)-(4). We present Angrist-Pischke F-statistics for the joint significance of instruments with multiple endogenous variables. 


\begin{tabular}{|c|c|c|c|c|c|c|c|}
\hline \multirow[t]{2}{*}{ First Stage } & \multicolumn{2}{|c|}{$\begin{array}{l}\text { Dep. var.: imports/sales } \\
\text { below threshold } f, t\end{array}$} & \multicolumn{2}{|c|}{$\begin{array}{l}\text { Dep. var.: imports/sales } \\
\text { above threshold } f, t\end{array}$} & \multirow[t]{2}{*}{ Second Stage } & \multicolumn{2}{|c|}{ Dep. var.: $\log (\text { skill ratio })_{f, t}$} \\
\hline & $(1)$ & $(2)$ & $(3)$ & $(4)$ & & $(5)$ & $(6)$ \\
\hline IV Supply Shock (below) & $\begin{array}{c}0.0023^{* * *} \\
(0.0007)\end{array}$ & $\begin{array}{c}0.0021^{* * *} \\
(0.0007)\end{array}$ & $\begin{array}{l}0.0022^{*} \\
(0.0013)\end{array}$ & $\begin{array}{c}0.0021 \\
(0.0013)\end{array}$ & imports/sales (below) & $\begin{array}{c}4.7407^{* *} \\
(2.282)\end{array}$ & $\begin{array}{c}4.4903^{* *} \\
(2.220)\end{array}$ \\
\hline IV Supply Shock (above) & $\begin{array}{c}-0.0070^{* *} \\
(0.0034)\end{array}$ & $\begin{array}{c}-0.0066^{*} \\
(0.0034)\end{array}$ & $\begin{array}{c}0.0090^{* * *} \\
(0.0034)\end{array}$ & $\begin{array}{c}0.0091^{* *} \\
(0.0031)\end{array}$ & imports/sales (above) & $\begin{array}{c}-3.5204^{*} \\
(1.987)\end{array}$ & $\begin{array}{r}-2.8695 \\
(1.914)\end{array}$ \\
\hline $\log (\mathrm{TFP})_{f, t}$ & & $\begin{array}{c}-0.0046^{* *} \\
(0.0020)\end{array}$ & & $\begin{array}{c}-0.0155^{* * *} \\
(0.0033)\end{array}$ & $\log (\mathrm{TFP})_{f, t}$ & & $\begin{array}{r}-0.0238 \\
(0.035)\end{array}$ \\
\hline $\log (\text { employees })_{f, t}$ & & $\begin{array}{c}-0.0287^{* * *} \\
(0.0034)\end{array}$ & & $\begin{array}{c}-0.0200^{* * *} \\
(0.0067)\end{array}$ & $\log (\text { employees })_{f, t}$ & & $\begin{array}{c}-0.1710^{* *} \\
(0.081)\end{array}$ \\
\hline $\log (\text { capital/labor })_{f, t}$ & & $\begin{array}{l}-0.0028 \\
(0.0024)\end{array}$ & & $\begin{array}{l}-0.0007 \\
(0.0033)\end{array}$ & $\log (\text { capital/labor })_{f, t}$ & & $\begin{array}{r}-0.0350 \\
(0.022)\end{array}$ \\
\hline $\log (\text { exports })_{f, t}$ & & $\begin{array}{c}0.0087^{* * *} \\
(0.0007)\end{array}$ & & $\begin{array}{c}0.0107^{* * *} \\
(0.0009)\end{array}$ & $\log (\text { exports })_{f, t}$ & & $\begin{array}{l}0.0037 \\
(0.031)\end{array}$ \\
\hline F-statistic (Angrist-Pischke) & 17,01 & 12,47 & 15,81 & 11,51 & & & \\
\hline Observations & 46,780 & 46,780 & 46,780 & 46,780 & & 46,780 & 46,780 \\
\hline Firms & 8,930 & 8,930 & 8,930 & 8,930 & & 8,930 & 8,930 \\
\hline Sample & importers & importers & importers & importers & & importers & importers \\
\hline Firm FE & YES & YES & YES & YES & & YES & YES \\
\hline Time FE & YES & YES & YES & YES & & YES & YES \\
\hline Cluster & Firm & Firm & Firm & Firm & & Firm & Firm \\
\hline
\end{tabular}

Table A-6: Skill ratio of production and importing from labor-abundant countries (IV estimates).

The dependent variable in the second-stage regression (columns (5)-(6)) is the firm-level (log) skill ratio of production, defined as the ratio of non-production workers to production workers. The main explanatory variable of interest is the ratio of imports from set of labor-abundant countries relative to sales (import/sales below threshold). The specifications also include the ratio of imports from the set of skill-abundant countries relative to sales (imports/sales above threshold). We consider imports from countries with less than 80 percent of the French level of secondary schooling. Other controls are (all at the firm level and in logs): TFP (constructed with the Levinsohn-Petrin method), the number of employees, the capital-labor ratio and the value of exports. Both imports/sales below and above threshold are considered endogenous. Instruments are constructed from foreign supply-shocks (see data section for an explanation). First-stage regressions are reported in columns (1)-(4). We present Angrist-Pischke F-statistics for the joint significance of instruments with multiple endogenous variables. 


\begin{tabular}{|c|c|c|c|c|c|c|c|c|}
\hline \multicolumn{9}{|c|}{$\begin{array}{c}\text { dependent variable is } \log (\text { skill ratio })_{f, t} \\
\text { OLS Estimates }\end{array}$} \\
\hline & $(1)$ & $(2)$ & $(3)$ & $(4)$ & $(5)$ & $(6)$ & $(7)$ & $(8)$ \\
\hline skill intensity & $0.2716^{* * *}$ & $0.1827^{* * *}$ & $0.0614^{* *}$ & $0.0642^{* *}$ & $0.3469^{*}$ & $0.3564^{*}$ & $0.3416^{*}$ & $0.3501^{*}$ \\
\hline $\operatorname{imports}_{f, t}$ & $(0.074)$ & $(0.069)$ & $(0.030)$ & $(0.030)$ & $(0.192)$ & $(0.190)$ & $(0.194)$ & $(0.191)$ \\
\hline $\log (\mathrm{TFP})_{f, t}$ & & $0.5379 * * *$ & & -0.0091 & & -0.0101 & & -0.0098 \\
\hline & & $(0.020)$ & & $(0.013)$ & & $(0.014)$ & & $(0.014)$ \\
\hline $\log (\text { employees })_{f, t}$ & & $\begin{array}{c}-0.1879 * * * \\
(0.010)\end{array}$ & & $\begin{array}{c}-0.2665^{* * *} \\
(0.027)\end{array}$ & & $\begin{array}{c}-0.2794^{* * *} \\
(0.029)\end{array}$ & & $\begin{array}{c}-0.2784^{* * *} \\
(0.029)\end{array}$ \\
\hline $\log (\text { capital/labor })_{f, t}$ & & $\begin{array}{c}-0.0557 * * * \\
(0.011)\end{array}$ & & $\begin{array}{c}-0.0612^{* * *} \\
(0.018)\end{array}$ & & $\begin{array}{c}-0.0626^{* * *} \\
(0.019)\end{array}$ & & $\begin{array}{c}-0.0616^{* * *} \\
(0.019)\end{array}$ \\
\hline $\log (\text { imports })_{f, t}$ & & $\begin{array}{l}0.0640^{* * * *} \\
(0.007)\end{array}$ & & $\begin{array}{l}0.0226^{* * *} \\
(0.007)\end{array}$ & & $\begin{array}{l}0.0298^{* * * *} \\
(0.007)\end{array}$ & & $\begin{array}{c}0.0300^{* * *} \\
(0.007)\end{array}$ \\
\hline $\log (\text { exports })_{f, t}$ & & $\begin{array}{c}0.0347^{* * *} \\
(0.004)\end{array}$ & & $\begin{array}{l}0.0060 \\
(0.004)\end{array}$ & & $\begin{array}{l}0.0061 \\
(0.004)\end{array}$ & & $\begin{array}{l}0.0062 \\
(0.004)\end{array}$ \\
\hline Observations & 48,504 & 48,504 & 48,504 & 48,504 & 39,527 & 39,527 & 39,527 & 39,527 \\
\hline Firms & 12,086 & 12,086 & 12,086 & 12,086 & 7,833 & 7,833 & 7,858 & 7,858 \\
\hline Firm FE & NO & NO & YES & YES & YES & YES & YES & YES \\
\hline 4-digit sector FE & YES & YES & $\mathrm{NO}$ & NO & NO & $\mathrm{NO}$ & $\mathrm{NO}$ & NO \\
\hline Time FE & YES & YES & YES & YES & YES & YES & YES & YES \\
\hline Cluster & Firm & Firm & Firm & Firm & Firm & Firm & Firm & Firm \\
\hline R-squared & 0.2636 & 0.3395 & 0.0455 & 0.0620 & 0.0457 & 0.0634 & 0.0457 & 0.0634 \\
\hline \multicolumn{9}{|c|}{ First-stage regression: dependent variable is skill intensity of $\operatorname{imports}_{f, t}$} \\
\hline tariff-predicted skill intensity $_{f, t}$ & & & & & $\begin{array}{l}0.4153^{* * *} \\
(0.022)\end{array}$ & $\begin{array}{l}0.4147^{* * *} \\
(0.022)\end{array}$ & $\begin{array}{c}0.4164^{* * *} \\
(0.022)\end{array}$ & $\begin{array}{c}0.4158^{* * *} \\
(0.022)\end{array}$ \\
\hline supply-shock-predicted skill intensity ${ }_{f, t}$ & & & & & & & $\begin{array}{l}-0,0022 \\
(0.0022)\end{array}$ & $\begin{array}{l}-0,0023 \\
(0.0024)\end{array}$ \\
\hline F-statistic & & & & & 359.69 & 375.75 & 184.64 & 183.87 \\
\hline Hansen J statistic (p-value) & & & & & n.a. & n.a. & 0.83 & 0.46 \\
\hline
\end{tabular}

Table A-7: Skill ratio of production and the skill intensity of imports from labor-abundant countries: OLS and IV estimates.

Columns (1)-(4) present OLS estimates and columns (5)-(6) present IV estimates. The main explanatory variable of interest is the average skill intensit of imports from labor-abundant countries. For an explanation of the construction of this variable see the data description. We consider imports from countries with less than 80 percent of the French level of secondary schooling (see the main text for the results obtained using a 95 percent cutoff). Other controls are (all at the firm level and in logs): TFP (constructed with the Levinsohn-Petrin method), the number of employees, the capital-labor ratio, the value of imports and the value of exports. The skill intensity of imports is considered endogenous. The instruments are the tariff-predicted skill intensity of imports (columns 5 and 6 ) and the supply-shock predicted skill intensity of imports (columns (7) and (8)). See the data section for a discussion of the IV strategy. We report F-statistics for the joint significance of the instruments and the P-value for the Hansen over-identification test in ( $H_{0}$ : instruments uncorrelated with the residuals) 